\title{
Bioavailability of selected trace and rare earth elements to Juncus effusus L.: the potential role of de-icing chlorides in the roadside environment
}

\author{
Sabina Dołęgowska (D) Agnieszka Gałuszka • \\ Zdzisław M. Migaszewski $\cdot$ Karina Krzciuk
}

Received: 9 August 2021 / Accepted: 15 December 2021 / Published online: 6 January 2022

(C) The Author(s) 2022

\begin{abstract}
Background and aim The presence of chlorides in soils, e.g., from de-icing salts may change metal availability to plants.

Methods To assess the role of de-icing chlorides on bioavailability of metals, the samples of the rhizosphere soils, roots and shoots of Juncus effusus L. were collected monthly from April to June of 2019 in the vicinity of roads and analyzed for trace $(\mathrm{Ag}, \mathrm{Cd}$, $\mathrm{Co}, \mathrm{Cu}, \mathrm{Pb}, \mathrm{Zn}$ ) and rare earth elements (from $\mathrm{La}$ to $\mathrm{Lu})$.

Results Concentrations of $\mathrm{Cl}^{-}$were distinctly higher in the shoots than in the roots. Apart from $\mathrm{Cd}$, the concentration sequence of the other metals was as follows: rhizosphere soils $>$ roots $>$ shoots. The bioaccumulation and translocation factors indicated that $\mathrm{Cd}$ was the most preferably transported to the shoots as opposed to $\mathrm{Ag}, \mathrm{Co}, \mathrm{Pb}$ and REEs that showed a very low translocation potential. Negative correlations, which were noted between $\mathrm{Cu}$ and $\mathrm{Co}$ in the shoots
\end{abstract}

Responsible Editor: Adriano Sofo.

Supplementary Information The online version contains supplementary material available at https://doi. org/10.1007/s 11104-021-05278-0.

S. Dołęgowska $(\bowtie) \cdot$ A. Gałuszka $\cdot$ Z. M. Migaszewski K. Krzciuk

Analytical Chemistry and Environmental Geochemistry Department, Institute of Chemistry, Jan Kochanowski University, 7 Uniwersytecka St, 25-406 Kielce, Poland e-mail: sabina.dolegowska@ujk.edu.pl and $\mathrm{Cl}^{-}$in soils, revealed their role in salinity stress alleviation. All soil samples showed a positive anomaly of $\mathrm{Ce}$ and a negative anomaly of $\mathrm{Eu}$, whereas the shoots showed in turn a negative anomaly of $\mathrm{Ce}$ and a distinct positive anomaly of Eu. The lowest salinity factors $(\mathrm{K} / \mathrm{Na}, \mathrm{Ca} / \mathrm{Na})$ of the shoots resulted from an increase of salinity in J. effusus by higher sodium concentrations derived from de-icing $\mathrm{NaCl}$.

Conclusions De-icing agents may change the uptake of other elements. In natural habitats, the factors affecting this process include: type of element, soil metal concentrations and interactions, and individual plant features.

Keywords Juncus effusus L. · De-icing salts · Trace metals $\cdot$ Rare earth elements $\cdot$ Bioavailability

\section{Introduction}

Low concentrations of chlorides have a beneficial effect on plant growth and development (White and Broadley 2001). In contrast, an excess of this anion is an environmental stress factor. High salinity may lead to disturbances of photosynthesis and cellular water balance, but also to mobilization of trace metals $(\mathrm{Cd}$, $\mathrm{Cu}, \mathrm{Pb}, \mathrm{Zn}$ ) in soil (Li et al. 2010; Wang et al. 2020). Chlorides enter the environment with rainfall, fertilizers, sea spray or air pollution. In most countries of the temperate climate zone, chloride salts, e.g., sodium chloride $(\mathrm{NaCl})$, calcium and magnesium chlorides 
$\left(\mathrm{CaCl}_{2}, \mathrm{MgCl}_{2}\right)$ have been used as de-icing agents of road maintenance (Gałuszka et al. 2011). Unfortunately, this practice has many detrimental effects leading to degradation of roadside soils and vegetation (Bäckström et al. 2004; Czerniawska-Kusza et al. 2004; Ordóñez-Barona et al. 2018). Sodium chloride, which is the most often used de-icing salt, reaches soil releasing metals bound by organic matter, clay minerals and $\mathrm{Fe}$ - and Mn-oxyhydroxides. The abundance of $\mathrm{Na}^{+}, \mathrm{Ca}^{2+}$ and $\mathrm{Mg}^{2+}$ ions causes the cation exchange due to competition between major and trace metal ions, or in the presence of chlorides leads to formation of inorganic complexes (Cheng et al. 2018; Li et al. 2010).

Chloride complexes have a direct impact on metal bioavailability, for example, soluble cadmium complexes $\left(\mathrm{CdCl}_{\mathrm{n}}{ }^{(\mathrm{n}-2)}\right)$ increase $\mathrm{Cd}$ bioavailability leading to a direct uptake of these compounds or enhanced mass transport of $\mathrm{Cd}^{2+}$ ions (Cheng et al. 2018 and references therein; Wang et al. 2016). This process and its efficiency depend on several factors, including plant species, initial concentrations of $\mathrm{Cd}$ and $\mathrm{NaCl}$, and the type of habitat (soils, hydroponics). $\mathrm{Co}, \mathrm{Cu}$ and $\mathrm{Zn}$ also form soluble chloride complexes, therefore in the presence of $\mathrm{Cl}^{-}$ions, their bioavailability and content in plants may increase. Bäckström et al. (2004) found that concentrations of free $\mathrm{Cu}^{2+}$ in soil solutions increased during the winter season, suggesting that the $\mathrm{Cu}^{2+}$ ion exchange process can be highlighted by the presence of higher chloride contents derived from de-icing agents. However, most of the released $\mathrm{Cu}^{2+}$ ions are immediately bound by organic ligands, so there is no relationship between a soil chloride concentration and $\mathrm{Cu}$ accumulation by plants. It is noteworthy that the presence of chloride ions does not increase complexation of zinc, which occurs in soil mainly as $\mathrm{Zn}^{2+}$ ion (Usman et al. 2005 and references therein).

$\mathrm{Ag}$ and $\mathrm{Pb}$ form insoluble salts with chlorides $(\mathrm{AgCl}$, $\left.\mathrm{PbCl}_{2}\right)$ and soluble polychloride complexes $\left(\mathrm{AgCl}_{\mathrm{n}}{ }^{(\mathrm{n}-1)}\right.$, $\mathrm{PbCl}_{\mathrm{n}}^{(\mathrm{n}-2)}$ ). According to the free-ion model, the occurrence of chloride ions in aqueous solutions reduces silver bioavailability due to formation of insoluble $\mathrm{AgCl}$ salt, but bioavailability of chloride silver complexes differs both in soils and aquatic environments (Fortin and Campbell 2000; Langdon et al. 2015; Wang et al. 2016) observed that higher concentrations of chlorides in soils resulted in increased accumulation of $\mathrm{Ag}$ in the shoots of wheat (Triticum aestivum L. cv. Sunbrook).
This relationship was explained by formation of soluble and colloidal chloride complexes, and $\mathrm{AgCl}$ which is taken up by passive diffusion. The addition of $\mathrm{NaCl}$ also increases the availability of $\mathrm{Pb}$ due to formation of soluble complexes, and massive transport of $\mathrm{Pb}^{2+}$ ions. It was shown that the amount of insoluble $\mathrm{PbCl}_{2}$ is too small to significantly reduce the bioavailability of $\mathrm{Pb}$ and to decrease its content in plant tissues ( $\mathrm{Li}$ et al. 2010; Usman et al. 2005).

A recent review of the literature on this issue indicates that there are no studies describing the effect of salinity and chloride ions on the bioavailability of rare earth elements in plants. Complexation of these metals affects their diffusion from the soils to the root surfaces where they are blocked by lateral transfer pathway configuration. This suggests that the presence of organic and inorganic ligands may change their bioavailability and concentrations in plants (Liang et al. 2008). Considering the molar mass, light rare elements (LREE - from $\mathrm{La}$ to $\mathrm{Eu}$ ) are favoured by plants, but their uptake depends on several environmental and biological factors, including climate, topography, soil taxonomy, hydrology, physiology and genetics (Ding et al. 2007; Migaszewski and Gałuszka 2015).

Most studies on the effect of de-icing salts on trace metal mobilization are laboratory-based (Cheng et al. 2018; Fortin and Cambell 2000; Ghallab et al. 2007). Previous investigations, conducted in natural habitats, have mainly centered on accumulation of major ions $\left(\mathrm{Na}^{+}, \mathrm{Ca}^{2+}, \mathrm{Mg}^{2+}, \mathrm{Cl}^{-}\right)$and their effect on soil and plant conditions (Czerniawska-Kusza et al. 2004; Devitt et al. 2014; Gałuszka et al. 2011; OrdóñezBarona et al. 2018). Only a few researchers (Bäckström et al. 2004) have addressed this issue to trace metals. The main objectives of the present study were: (i) to examine seasonal changes in concentrations of selected trace and rare earth elements in the shoots, roots, and rhizosphere soils of Juncus effusus L. collected from roadsides exposed to de-icing salts $(\mathrm{NaCl})$, and (ii) to explain whether and how chloride concentrations affect the bioavailability of these metals.

\section{Materials and methods}

Study area

The city of Kielce is the capital of the Świętokrzyskie province (south central Poland). It is located in the 
central part of the Holy Cross Mountains (HCM) - a region that belongs to a separate climatic unit on the climatic map of Poland. Mean annual temperature in the Holy Cross Mountains is $1-2{ }^{\circ} \mathrm{C}$ lower than the mean temperature of the surrounding regions, whereas the mean annual precipitation is higher and exceeds $750 \mathrm{~mm}$ per year. The city lies within hills and valleys surrounded by forests. The geology of the region includes two main geologic units: the Łysogóry (north) and the Kielce (south). The latter encompasses several rock formations from the Lower Cambrian to the Lower Carboniferous. The study area is characterised by a high variability of soil types including rankers, cambisols, rendzinas, arenosols, podzols, fluvisols and chernozems (Dołęgowska et al. 2021).

The city of Kielce is located at a junction of major communication routes: Warsaw-Kraków and ŁódźRzeszów (Fig. 1). Numerous local roads connect the surrounding villages with the city, allowing their residents to commute to work. The maintenance of main and local roads during the winter needs using chemical de-icers. In Poland the most commonly used road salt is a mixture of sodium chloride $(97 \%$ $\mathrm{NaCl}$ ), calcium chloride $\left(2.5 \% \mathrm{CaCl}_{2}\right)$ and potassium hexacyanoferrate(II) $\left(0.5 \% \mathrm{~K}_{4}\left[\mathrm{Fe}(\mathrm{CN})_{6}\right]\right)$, which is added to avoid salt clumping. Road services are reluctant to use alternative salts $\left(\mathrm{CaCl}_{2}\right.$ and $\left.\mathrm{MgCl}_{2}\right)$ due to their higher price and hygroscopicity. Of these two salts, calcium chloride is more commonly used, although it is also considered less environmentally friendly than magnesium chloride (Gałuszka et al. 2011).

The winter of 2018/2019 preceding the sampling year was quite mild. January was the coldest month, with an average temperature of around $-5{ }^{\circ} \mathrm{C}$. The average temperatures of December and February were around 0 and $4{ }^{\circ} \mathrm{C}$, respectively. Snowfall was also below average (Weatheronline.pl/weather/maps/ city).

\section{Fieldworks}

The basic criterion for the selection of sampling sites was the occurrence of $J$. effusus in roadside ditches. Therefore, two sampling sites (\#4 and 5) were located within the city, sites \#1, 6 and 7 were situated by main roads toward Warsaw, Opatów and Nowa Słupia, whereas sites \#2 and 3 by rural roads (Fig. 1). The shoots, roots, and rhizosphere soils of $J$. effusus were collected during three sampling campaigns, in April, May and June of 2019, respectively.

Samples were taken from roadside ditches with trapezoidal cross-section extending along roads except for the sample from site \#5 collected from a roadside open space, about $3 \mathrm{~m}$ from the road

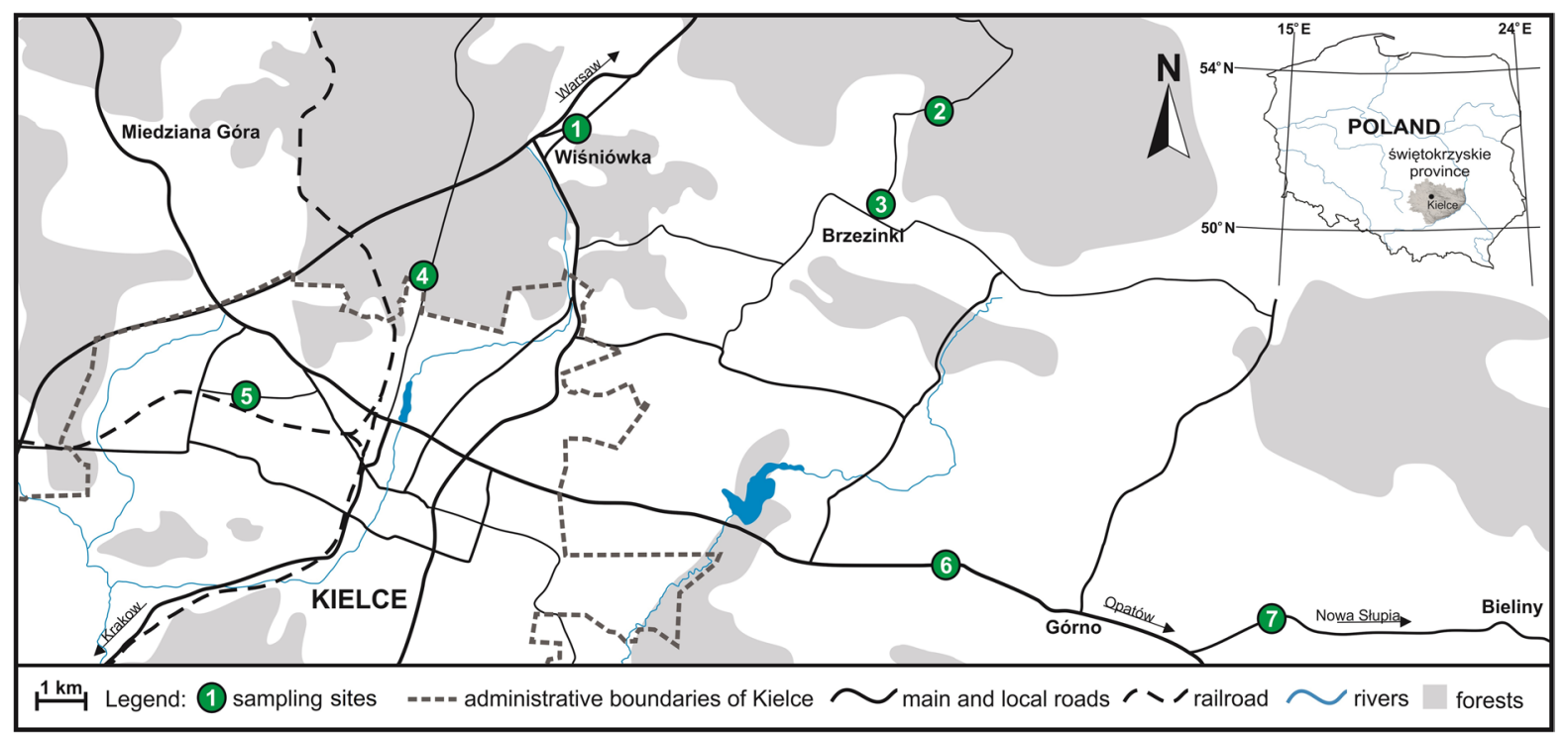

Fig. 1 Sketch map of the study area 
shoulder. The ditches reached about $0.5 \mathrm{~m}$ in depth. Their profile was uneven and variable, they were also steeply sloped and covered with vegetation along almost their entire length. Light grey-brown and greybrown sandy soil predominated at sites \#1-4 and 7, 8 , whereas grey-brown sandy loam soil was found at sites \# 5 and 6.

Plants (shoots and roots) and soils were collected according to the methodology described earlier by Kovacheva et al. (2000) and Krzciuk (2019, 2020). The mean height of the plants was $30 \mathrm{~cm}$ in April and 40-50 $\mathrm{cm}$ in May and June. The composite shoot samples (from 3 to 5 increments depending on the sampling site) were collected about 3-4 $\mathrm{cm}$ above the soils cover. The weight of single sample was about $100 \mathrm{~g}$. Soil surrounding the J. effusus roots (from a depth of 0.15 to $0.20 \mathrm{~m}$ ) was carefully separated from the roots to avoid their mechanical damages. Subsequently, each soil sample weighing about $500 \mathrm{~g}$ was in situ cleaned from external material, oversized particles $(\varnothing>2 \mathrm{~mm})$, and mixed. The roots were carefully cleaned from a remaining adhered material and mixed. Afterward, the cleaned samples were separately packed in a polyethylene bags and transported to the laboratory.

\section{Why Juncus effusus?}

Juncus effusus L. is a widely distributed perennial macrophyte preferring humid habitats and wetlands. The preference for water-logging conditions has resulted in formation of an aerenchyma tissue that contains enlarged gas spaces as a response on abiotic stress caused by hypoxia. Due to this characteristic, the plant can release oxygen into the rhizosphere, thus changing redox conditions and bioavailability of metals (Syranidou et al. 2017). J. effusus has also a wide ecological tolerance, which is evidenced by a high resistivity to several toxic metal(loid)s. Due to this ability, it has been widely used in phytoremediation for removal trace metal(loid) and organic pollutants (Bouldin et al. 2006; Rahman et al. 2014; Syranidou et al. 2017; Wiessner et al. 2013; Zare et al. 2020). This high tolerance makes $J$. effusus like halophytes, salt-tolerant plants growing on soils or waters of high salinity (Krzciuk and Gałuszka 2019, 2020; Peng et al. 2018). Analysis of the Juncus sp. shoots growing on contaminated wetland in the margin of a saline lake in Iran (Zare et al. 2020) confirmed that this plant can accumulate and stabilize trace metals in tissues under high salinity conditions. Studies from the Holy Cross Mountains (Krzciuk and Gałuszka 2019, 2020) have shown that Mn, Zn, and Cd are most efficiently transferred from the root to the shoot, in contrast to $\mathrm{Pb}$ and REEs whose transfer is constrained.

\section{Sample preparation}

As mentioned before, the samples were transported to the laboratory and prepared for further analysis. The process of sample treatment is presented in Fig. 2.

Analysis of total $\mathrm{Cl}$ in shoots and roots of $\mathrm{J}$. effusus

The shoots and roots were analyzed for the total chlorine content using a portable XRF analyser (model Thermo Scientific NITON XL3t 960 GOLDD+) with an excitation source $50 \mathrm{kV}$ X-ray tube with $\mathrm{Ag}$ anode. The detection mode was set on "ALL GEO". The time of FPXRF analysis was $120 \mathrm{~s}$. Measurements were done in triplicates and precision was expressed as 2 standard deviations of the mean values. The emission spectra were transferred to the PC and appropriately processed with the use of the Niton Data Transfer software. The Apple leaves (CRM-1515) and Tobacco leaves (CTA-VTL-2) as certified reference materials were used to ensure the quality control. The recovery values were in the range of 92 to $111 \%$.

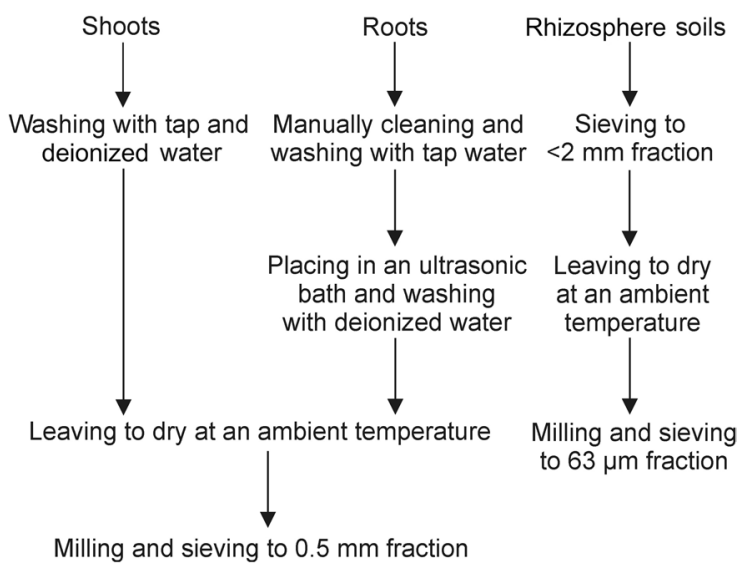

Fig. 2 Details of sample preparation procedure 
Analysis of $\mathrm{pH}, \mathrm{EC}$, and exchangeable chlorides in rhizosphere soil water extracts

Soil samples weighing $10 \mathrm{~g}$ each were placed in beakers, mixed with $25 \mathrm{~mL}$ of deionized water, and agitated for $24 \mathrm{~h}(\sim 140 \mathrm{mph})$. Subsequently, the samples were filtrated, and the obtained extracts were used for measurements of pH (model SP 300, Slandi, Poland), EC (model SC300, Slandi, Poland) and chloride concentrations (portable spectrophotometer, model LF300, Slandi, Poland).

Analysis of major, trace and rare earth elements

The shoot and root samples weighing $0.5 \mathrm{~g}$ were digested in a closed microwave system (Multiwave 3000, Anton Paar, Austria) with $8 \mathrm{~mL}$ of $\mathrm{HNO}_{3}$ (1:1) (Suprapur®) and $1 \mathrm{~mL}$ of $30 \% \mathrm{H}_{2} \mathrm{O}_{2}$ (Suprapur®). The rhizosphere soil samples (0.5 g each) were digested in $8 \mathrm{~mL}$ of aqua regia $\left(6 \mathrm{~mL}\right.$ of $30 \% \mathrm{HCl}$ Suprapur ${ }^{\circledR}$ and $2 \mathrm{~mL}$ of $65 \% \mathrm{HNO}_{3}$ Suprapur®) solution. After digestion, the samples were diluted to $25 \mathrm{~mL}$ with deionized water and filtered to disposable Falcon tubes (Dołęgowska and Migaszewski 2013; Krzciuk and Gałuszka 2019, 2020; Loell et al. 2011). The digestion parameters are presented in Table 1 of ESM. To ensure the quality control, blank samples and certified reference materials were prepared using the same digestion procedures. The glassware was prepared by washing with a detergent, rinsing, and soaking in $5 \% \mathrm{HNO}_{3}$ for 1 week. Subsequently, it was rinsed with deionized water and dried. The digested solutions were analyzed for major ( $\mathrm{Na}, \mathrm{K}, \mathrm{Ca}, \mathrm{Mg}$ ), trace ( $\mathrm{Ag}, \mathrm{Cd}, \mathrm{Pb}, \mathrm{Co}, \mathrm{Cu}$, $\mathrm{Zn}$ ) and rare earth elements using the FAAS (model iCE 3000, ThermoScientific) and ICP-MS techniques (model ELAN DRC II, Perkin Elmer). Prior to the analysis, the AAS instrument was optimized and calibrated with Certipur ${ }^{\circledR}$ Single-Element Standards for Atomic Absorption Spectroscopy. The ICP-MS instrument was optimized with a standard daily procedure and the calibration was done with Perkin Elmer Multielement Calibration Standards. Iridium and rhodium internal standards were added to all samples to control instrument drift. Moreover, for $\mathrm{Nd}, \mathrm{Sm}, \mathrm{Gd}$, Dy, and $\mathrm{Yb}$ the correction equations were introduced to eliminate individual interferences. The average percentage recovery (range of 80 to $110 \%$ ) was calculated using the following certified reference materials: for soils - GSS4, GSS7 (Chinese Academy of Geological Sciences),
Montana I Soil (2710a), for shoots and roots - Tomato leaves (1573a) and Peach leaves (1547).

Statistical analysis

Data analysis was performed by using STATISTICA StatSoft ${ }^{\circledR}$ and Microsoft ${ }^{\circledR}$ Excel. The Kruskall-Wallis test $(p<0.05)$ was done to find differences between sampling sites and sampling seasons. In turn, Spearman's rank coefficients $(p<0.05)$ were computed to find correlations between all parameters examined (Table 2 of ESM).

Bioconcentration, translocation and salinity factors

Bioaccumulation (BAF) and translocation (TF) factors were calculated according to the following equations:

$$
\begin{aligned}
& B A F=c_{\text {shoot }}\left(m g \cdot k g^{-1}\right) / c_{\text {soil }}\left(m g \cdot k g^{-1}\right) \\
& T F=c_{\text {shoot }}\left(m g \cdot \mathrm{kg}^{-1}\right) / c_{\text {root }}\left(m g \cdot \mathrm{kg}^{-1}\right)
\end{aligned}
$$

Where:

$c_{\text {shoot }}$ - the metal concentration in shoot,

$c_{\text {soil }}$ - the metal concentration in rhizosphere soil,

$c_{\text {root }}$ - the metal concentration in root.

The salinity factors were expressed as $\mathrm{K} / \mathrm{Na}$ and $\mathrm{Ca} /$ $\mathrm{Na}$ ratios, and computed in relation to the K, $\mathrm{Ca}$ and $\mathrm{Na}$ concentrations in soils and shoots (Table 3 of ESM).

Normalized patterns and anomalies of REE

To eliminate the Oddo-Harkins effect occurring in the group of rare earth elements, the results were normalized to North American Shale Composite (NASC), which is used as a standard material for normalization (Bau et al. 2018). The normalized patterns are presented in Fig. 3. The individual anomalies were computed using double-sided elements showing no anomalies (Dołęgowska et al. 2017) and are compiled in Table 2.

\section{Results}

$\mathrm{pH}, \mathrm{EC}$ and $\mathrm{Cl}$

Table 1 presents the summary statistics (ranges, means, standard deviations) for $\mathrm{pH}, \mathrm{EC}$ and elements 
in the rhizosphere soils, roots, and shoots of roadside J. effusus collected within three sampling campaigns, in April, May and June of 2019. The pH of rhizosphere soil solutions ranged from 6.0 to 7.9 , with mean values of 7.3 (April), 7.2 (May), 7.3 (June). The electric conductivity (EC) of soil extracts varied from 198 to $2982 \mu \mathrm{S} \bullet \mathrm{cm}^{-1}$ with the lowest mean value in April $\left(501 \mu \mathrm{S} \bullet \mathrm{cm}^{-1}\right)$ and the highest in June (994 $\mu \mathrm{S} \bullet \mathrm{cm}^{-1}$ ). The concentrations of $\mathrm{Cl}^{-}$in the rhizosphere soil solutions varied from 8.60 to $49.6 \mathrm{mg} \cdot \mathrm{L}^{-1}$. The mean $\mathrm{Cl}^{-}$contents in samples collected in different months were as follows: April $-21.0 \mathrm{mg} \bullet \mathrm{L}^{-1}$, May - $23.8 \mathrm{mg} \cdot \mathrm{L}^{-1}$, June - $22.0 \mathrm{mg} \bullet \mathrm{L}^{-1}$. Chloride concentrations in the roots ranged from 973 to $9420 \mathrm{mg} \cdot \mathrm{kg}^{-1}$, whereas in the shoots from 3598 to $12,672 \mathrm{mg} \cdot \mathrm{kg}^{-1}$. Statistically significant differences between the concentrations of $\mathrm{Cl}^{-}$in samples collected are marked in Table 1.

\section{Major and trace elements}

Concentrations of $\mathrm{Cd}$ in our samples were in the range of $0.170 \mathrm{mg} \cdot \mathrm{kg}^{-1}$ (shoots) to $6.35 \mathrm{mg} \cdot \mathrm{kg}^{-1}$ (roots) and varied according to the sampling sites and the type of sample. The lowest mean values were noted in the rhizosphere soils $\left(0.771 \mathrm{mg} \cdot \mathrm{kg}^{-1}\right)$ and the highest in the roots $\left(2.00 \mathrm{mg}^{\circ} \mathrm{kg}^{-1}\right) . \mathrm{Zn}$ contents ranged from $17.7 \mathrm{mg} \cdot \mathrm{kg}^{-1}$ (shoots) to $341 \mathrm{mg} \cdot \mathrm{kg}^{-1}$ (rhizosphere soils), with mean values of $43.6 \mathrm{mg} \cdot \mathrm{kg}^{-1}$ (shoots), $90.2 \mathrm{mg} \cdot \mathrm{kg}^{-1}$ (roots) and $152 \mathrm{mg} \cdot \mathrm{kg}^{-1}$ (soils). The mean concentrations of $\mathrm{Cu}$ were $4.15 \mathrm{mg} \cdot \mathrm{kg}^{-1}$ (shoots), $10.3 \mathrm{mg} \cdot \mathrm{kg}^{-1}$ (roots), and $20.4 \mathrm{mg} \cdot \mathrm{kg}^{-1}$ (rhizosphere soils), whereas the concentrations of Co varied from 0.033 (shoots) to $23.0 \mathrm{mg} \bullet \mathrm{kg}^{-1}$ (rhizosphere soils) with the lowest mean levels in April (9.65 $\mathrm{mg} \bullet \mathrm{kg}^{-1}$ rhizosphere soils, $1.33 \mathrm{mg} \bullet \mathrm{kg}^{-1}$ - roots) and in June $\left(0.089 \mathrm{mg} \mathrm{kg}^{-1}-\right.$ shoots). In our research the mean concentrations of $\mathrm{Ag}$ were: $0.109 \mathrm{mg} \cdot \mathrm{kg}^{-1}$ (rhizosphere soils), $0.072 \mathrm{mg} \mathrm{kg}^{-1}$ (roots) and $0.009 \mathrm{mg} \cdot \mathrm{kg}^{-1}$ (shoots), whereas the concentrations of $\mathrm{Pb}$ in shoots varied from 0.006 to $1.20 \mathrm{mg} \cdot \mathrm{kg}^{-1}$ and were much lower than those in the roots (2.56$32.1 \mathrm{mg} \cdot \mathrm{kg}^{-1}$ ) and soils (17.7-104 $\mathrm{mg} \bullet \mathrm{kg}^{-1}$ ) (Table 1).

The obtained mean values of REE were as follows: $0.018 \mathrm{mg} \bullet \mathrm{kg}^{-1}$ for shoots, $1.12 \mathrm{mg} \bullet \mathrm{kg}^{-1}$ for the roots and $6.45 \mathrm{mg} \bullet \mathrm{kg}^{-1}$ for the rhizosphere soils. The $\mathrm{La}_{\mathrm{NASC}} / \mathrm{Yb}_{\mathrm{NASC}}, \mathrm{La}_{\mathrm{NASC}} / \mathrm{Sm}_{\mathrm{NASC}}$ and $\mathrm{Sm}_{\mathrm{NASC}}$ ' $\mathrm{Yb}_{\mathrm{NASC}}$ ratios were in the ranges of 1.09-2.85,
0.57-2.64, 0.52-17.5, respectively (Table 2). The computed $\mathrm{Ce} / \mathrm{Ce}_{\mathrm{NASC}}$ and $\mathrm{Eu} / \mathrm{Eu}_{\mathrm{NASC}}$ values indicating the predominant positive anomaly of $\mathrm{Ce}$ in the rhizosphere soils (1.09-1.27) and the negative anomaly in the shoots (0.11-1.01) and the prevailing negative anomaly of $\mathrm{Eu}$ in the soils (0.71$1.03)$ and the strong positive anomaly in the shoots (1.36-13.7).

\section{Spearman's rank correlation coefficients}

The influence of $\mathrm{Cl}^{-}$on metal availability was assessed by the Spearman's rank correlation coefficients (Table 2 of ESM). Taking into consideration the type of sample and the month of collection, statistically significant coefficients were recorded for the following pairs: in April $-\mathrm{Cd}_{\text {roots }}-\mathrm{Cl}_{\text {roots }}-0.86$, $\mathrm{Co}_{\text {soils }}-\mathrm{Cl}_{\text {roots }}-0,79$; in June $-\mathrm{Cd}_{\text {soils }}-\mathrm{Cl}_{\text {shoots }}-0.79$, $\mathrm{Cd}{ }_{\text {roots }}-\mathrm{Cl}_{\text {soils }}-0.82, \mathrm{Cu}_{\text {roots/shoots }}-\mathrm{Cl}_{\text {soils }}-0.86,-0.89$, $\mathrm{Pb}_{\text {soils }}-\mathrm{Cl}_{\text {shoots }}-0.79, \mathrm{~Pb}_{\text {roots }}-\mathrm{Cl}_{\text {soils }}-0.72$. As for REE, significant correlations were obtained: in April between $\mathrm{La}, \mathrm{Ce}, \mathrm{Ho}, \mathrm{Er}$ and $\mathrm{Tm}$ in roots and $\mathrm{Cl}^{-}$in soils (the range of coefficients varied from 0.79 to 0.86 ); in May between $\mathrm{Tb}$ and $\mathrm{Yb}$ in the shoots and $\mathrm{Cl}^{-}$in the roots (0.79 in both cases), and in June between $\mathrm{Ce}, \mathrm{Pr}, \mathrm{Nd}, \mathrm{Gd}, \mathrm{Tb}, \mathrm{Tm}$ and $\mathrm{Lu}$ in the shoots and $\mathrm{Cl}^{-}$in shoots (0.82-0.96). Bioavailability of metals depends also on their interactions, which in turn are directly related to their role in plant and content in soil. Relationships between metals in all samples examined, expressed as the significant Spearman's coefficients were as follows: in April $-\mathrm{Cu}_{\text {soils }}-\mathrm{Ag}_{\text {soils }}$ $0.93, \mathrm{Cu}_{\text {roots }}-\mathrm{Ag}_{\text {roots/shoots }} 0.93,0.82, \mathrm{Cu}_{\text {shoots }}-\mathrm{Cd}_{\text {shoots }}$ 0.89, $\mathrm{Cu}_{\text {soils }}-\mathrm{Co}_{\text {soil }} \quad 0.82, \mathrm{Zn}_{\text {soils/roots }}-\mathrm{Cd}_{\text {roots }} \quad 0.89$, 0.93; in May - $\mathrm{Cd}_{\text {soils }}-\mathrm{Ag}_{\text {soils }} 0.78, \mathrm{Cd}_{\text {shoots }}-\mathrm{Ag}_{\text {shoots }}$ 0.95, $\mathrm{Cd}_{\text {roots }}-\mathrm{Cd}_{\text {soils }} \quad 0.93, \mathrm{Co}_{\text {soils/roots }}-\mathrm{Ag}_{\text {soils }}$ 0.86, $0.78, \mathrm{Co}_{\text {roots/shoots }}-\mathrm{Ag}_{\text {roots }} 0.86,0.86, \mathrm{Co}_{\text {roots }}-\mathrm{Co}_{\text {shoots }}$ 0.93, $\quad \mathrm{Cu}_{\text {soils/shoots }}-\mathrm{Cd}_{\text {soils/shoots }} \quad 0.86, \quad 0.82$, $\mathrm{Pb}_{\text {shoots }}-\mathrm{Ag}_{\text {shoots }} / \mathrm{Pb}_{\text {roots }} \quad 0.78, \quad 0.86, \quad \mathrm{~Pb}_{\text {roots }}-\mathrm{Cu}_{\text {roots }}$ ' $\mathrm{Pb}_{\text {soils }} 0.82,0.93, \mathrm{Zn}_{\text {soils }}-\mathrm{Cd}, \mathrm{Cu}_{\text {soils }} 0.82,0.89$, and in June $-\mathrm{Cd}_{\text {soils }}-\mathrm{Ag}_{\text {soils }}$ 0.61, $\mathrm{Cd}_{\text {shoots }}-\mathrm{Ag}_{\text {shoots }}$ 0.93, $\mathrm{Cu}_{\text {soils }}-\mathrm{Ag}_{\text {soils }} \quad 0.82, \mathrm{Cu}_{\text {shoots }}-\mathrm{Ag}_{\text {shoots }} 0.82$, $\mathrm{Pb}_{\text {soils }}-\mathrm{Ag}_{\text {soils }}$ 0.96, $\mathrm{Pb}_{\text {roots }}-\mathrm{Cu}_{\text {roots }} 0.93, \mathrm{Zn}_{\text {soils }}-\mathrm{Cd}$, $\mathrm{Cu}_{\text {soils }}$ 0.89, 0.79. Significant correlations between individual REEs and other elements ranged from -0.86 to 0.96 (Table 2 of ESM) and depended on the element and the type of sample. 
Table 1 The $\mathrm{pH}$, electric conductivity (EC) and element concentrations in rhizosphere soils, roots, and shoots of roadside $J$. effusus

\begin{tabular}{|c|c|c|c|c|c|c|c|c|c|}
\hline $\begin{array}{l}\text { Month of } \\
\text { collection }\end{array}$ & April & May & June & April & May & June & April & May & June \\
\hline Parameter & \multicolumn{3}{|c|}{ Rhizosphere soils } & \multicolumn{3}{|l|}{ Roots } & \multicolumn{3}{|l|}{ Shoots } \\
\hline $\mathrm{pH}$ & $6.0-7.9$ & $6.4-7.6$ & $6.8-7.8$ & - & - & - & - & - & - \\
\hline $\bar{x} \pm \sigma$ & $7.3 \pm 0.6$ & $7.2 \pm 0.4$ & $7.3 \pm 0.4$ & - & - & - & - & - & - \\
\hline $\begin{array}{l}\mathrm{EC} \\
\qquad\left(\mu \mathrm{S} \bullet \mathrm{cm}^{-1}\right)\end{array}$ & $236-928$ & 209-1194 & $198-2982$ & - & - & - & - & - & - \\
\hline $\bar{x} \pm \sigma$ & $501 \pm 258$ & $631 \pm 345$ & $994 \pm 943$ & - & - & - & - & - & - \\
\hline $\mathrm{Cl}\left(\mathrm{mg} \cdot \mathrm{L}^{-1}\right)$ & $10.7-30.2$ & $12.0-49.6$ & $8.60-43.3$ & - & - & - & - & - & - \\
\hline $\begin{array}{l}\bar{x} \pm \boldsymbol{\sigma} \\
\mathrm{mg} \cdot \mathrm{kg}^{-1}\end{array}$ & $21.0 \pm 9.31$ & $23.8 \pm 13.5$ & $22.0 \pm 11.7$ & - & - & - & - & - & - \\
\hline $\mathrm{Cl}$ & - & - & - & $973-9420$ & $1769-6516$ & $2532-9180$ & $3598-12672$ & $3849-9403$ & $7031-12674$ \\
\hline $\bar{x} \pm \sigma$ & - & - & - & $3601 \pm 2776^{* *}$ & $4389 \pm 1692 * *$ & $4909 \pm 2387 * *$ & $7083 \pm 2810^{* *}$ & $7240 \pm 1838 * *$ & $9479 \pm 2347 * *$ \\
\hline $\mathrm{Ag}$ & $0.060-0.185$ & $0.066-0.142$ & $0.065-0.224$ & $0.025-0.168$ & $0.022-0.240$ & $0.013-0.215$ & $0.004-0.042$ & $0.002-0.003$ & $0.003-0.002$ \\
\hline $\bar{x} \pm \sigma$ & $0.102 \pm 0.044$ & $0.09 \pm 0.028$ & $0.127 \pm 0.058$ & $0.052 \pm 0.052$ & $0.071 \pm 0.080$ & $0.093 \pm 0.088$ & $0.015 \pm 0.013$ & $0.008 \pm 0.001$ & $0.006 \pm 0.006$ \\
\hline $\mathrm{Cd}$ & $0.410-1.08$ & $0.420-1.83$ & $0.376-2.01$ & $0.752-1.64$ & $0.832-5.72$ & $0.805-6.35$ & $0.272-3.06$ & $0.269-2.84$ & $0.170-0.863 * *$ \\
\hline $\bar{x} \pm \sigma$ & $0.628 \pm 0.222$ & $0.857 \pm 0.518$ & $0.829 \pm 0.587$ & $1.17 \pm 0.299$ & $2.55 \pm 1.99$ & $2.29 \pm 2.03$ & $1.26 \pm 1.17$ & $1.25 \pm 0.874$ & $0.415 \pm 0.261$ \\
\hline Co & $5.25-16.5$ & $6.08-23.0$ & $5.19-22.1$ & $1.33-8.06$ & $2.12-14.2$ & $1.59-7.27$ & $0.034-0.465$ & $0.033-0.280$ & $0.048-0.148$ \\
\hline $\bar{x} \pm \sigma$ & $9.65 \pm 4.34$ & $10.1 \pm 5.96$ & $10.7 \pm 5.54$ & $4.01 \pm 2.40$ & $5.71 \pm 4.01$ & $5.21 \pm 2.04$ & $0.128 \pm 0.157$ & $0.117 \pm 0.081$ & $0.089 \pm 0.035^{* *}$ \\
\hline $\mathrm{Cu}$ & $9.06-26.6$ & $9.73-27.9$ & $10.7-43.4$ & $4.67-13.7$ & $6.74-20.2$ & $3.62-16.4$ & $1.30-6.03$ & $1.46-6.72$ & $1.64-7.06$ \\
\hline $\bar{x} \pm \sigma$ & $18.2 \pm 7.27$ & $19.1 \pm 7.53$ & $23.9 \pm 11.9$ & $9.27 \pm 3.02$ & $11.6 \pm 5.00$ & $9.91 \pm 5.17$ & $3.50 \pm 1.74$ & $4.47 \pm 2.16$ & $4.46 \pm 1.63$ \\
\hline $\mathrm{Pb}$ & $17.7-104$ & $18.2-73.8$ & $19.0-89.4$ & $3.95-16.4$ & $7.04-25.1$ & $2.56-32.1$ & $0.259-0.752$ & $0.175-0.752$ & $0.006-1.20$ \\
\hline $\bar{x} \pm \sigma$ & $45.9 \pm 31.0$ & $47.5 \pm 23.8$ & $52.8 \pm 32.4$ & $9.86 \pm 4.31$ & $15.2 \pm 6.42$ & $11.5 \pm 10.2$ & $0.396 \pm 0.173$ & $0.332 \pm 0.203$ & $0.222 \pm 0.432$ \\
\hline $\mathrm{Zn}$ & $95.1-218$ & $100-291$ & $106-341$ & 38.6-102 & $52.3-245$ & 48.6-197 & $30.2-97.8$ & $24.8-82.5$ & $17.7-40.6$ \\
\hline $\begin{array}{l}\overline{\boldsymbol{x}} \pm \boldsymbol{\sigma} \\
\mathrm{mg} \cdot \mathrm{kg}^{-1}\end{array}$ & $123 \pm 44.2$ & $168 \pm 76.5$ & $166 \pm 83.1$ & $58.3 \pm 22.8$ & $117 \pm 71.3$ & $\begin{array}{c}95.6 \pm 50.4 \\
\mu g \bullet \mathrm{kg}^{-1}\end{array}$ & $54.2 \pm 22.7$ & $54.8 \pm 20.9$ & $29.8 \pm 8.60 * *$ \\
\hline $\mathrm{La}$ & $12.7-29.9$ & $12.6-27.4$ & $12.5-29.4$ & $1.78-6.15$ & $1.55-4.36$ & $0.734-5.021$ & $19.6-248$ & $12.8-349$ & $<0.500-130$ \\
\hline $\bar{x} \pm \sigma$ & $21.3 \pm 5.69$ & $19.0 \pm 4.46$ & $19.2 \pm 6.09$ & $3.33 \pm 1.60$ & $3.22 \pm 1.07$ & $2.41 \pm 1.58$ & $58.6 \pm 84.1$ & $125 \pm 115$ & $37.4 \pm 24.6^{*}$ \\
\hline $\mathrm{Ce}$ & $32.8-63.5$ & $33.2-58.6$ & $32.49-62.5$ & $3.27-15.7$ & $2.97-9.94$ & $1.09-11.4$ & $12.7-417$ & $6.57-368$ & $12.5-169$ \\
\hline $\bar{x} \pm \sigma$ & $46.0 \pm 10.9$ & $41.4 \pm 8.50$ & $42.7 \pm 11.3$ & $7.45 \pm 4.42$ & $6.78 \pm 2.39$ & $5.24 \pm 0.686$ & $88.3 \pm 146$ & $129 \pm 131$ & $47.3 \pm 57.3$ \\
\hline $\operatorname{Pr}$ & $2.90-5.50$ & $2.99-5.13$ & $2.91-5.39$ & $0.36-1.45$ & $0.347-1.10$ & $0.119-1.31$ & $0.550-47.0$ & $0.57-40.5$ & $3.39-18.1$ \\
\hline $\bar{x} \pm \sigma$ & $4.14 \pm 0.963$ & $3.72 \pm 0.709$ & $3.80 \pm 0.916$ & $0.825 \pm 0.398$ & $0.801 \pm 0.291$ & $0.580 \pm 0.416$ & $9.68 \pm 16.6$ & $14.1 \pm 14.4$ & $4.95 \pm 6.15$ \\
\hline $\mathrm{Nd}$ & $8.82-16.7$ & $9.12-15.9$ & $8.75-16.4$ & $1.44-5.02$ & $1.39-4.50$ & $0.449-5.37$ & $1.65-176$ & $0.67-143$ & $1.48-69.6$ \\
\hline $\bar{x} \pm \sigma$ & $12.8 \pm 3.08$ & $11.5 \pm 2.20$ & $11.8 \pm 2.87$ & $3.19 \pm 1.36$ & $3.23 \pm 1.23$ & $2.33 \pm 1.69$ & $32.7 \pm 63.5$ & $49.8 \pm 54.2$ & $17.0 \pm 24.2$ \\
\hline $\mathrm{Sm}$ & $2.12-4.34$ & $2.22-4.10$ & $2.14-4.19$ & $0.277-1.19$ & $0.269-0.936$ & $0.111-1.14$ & $1.29-39.7$ & $1.91-32.41$ & $<0.500-16.4$ \\
\hline $\bar{x} \pm \sigma$ & $3.23 \pm 0.857$ & $2.90 \pm 0.621$ & $2.98 \pm 0.774$ & $0.703 \pm 0.349$ & $0.660 \pm 0.262$ & $0.489 \pm 0.349$ & $8.96 \pm 13.7$ & $12.2 \pm 11.2$ & $5.32 \pm 5.51 *$ \\
\hline $\mathrm{Eu}$ & $0.321-0.907$ & $0.334-0.843$ & $0.325-0.863$ & $0.053-0.252$ & $0.059-0.215$ & $0.039-0.228$ & $2.40-11.3$ & $2.77-13.6$ & $2.71-6.33$ \\
\hline $\bar{x} \pm \sigma$ & $0.601 \pm 0.234$ & $0.509 \pm 0.170$ & $0.549 \pm 0.186$ & $0.160 \pm 0.082$ & $0.143 \pm 0.063$ & $0.110 \pm 0.067$ & $4.42 \pm 3.15$ & $5.59 \pm 4.07$ & $3.98 \pm 1.34$ \\
\hline Gd & $2.00-4.17$ & $2.08-4.02$ & $2.06-4.05$ & $0.261-1.15$ & $0.288-0.968$ & $0.106-0.1089$ & $1.06-34.4$ & $1.91-35.4$ & $1.32-16.8$ \\
\hline $\bar{x} \pm \sigma$ & $3.15 \pm 0.845$ & $2.81 \pm 0.637$ & $2.88 \pm 0.762$ & $0.717 \pm 0.356$ & $0.664 \pm 0.271$ & $0.402 \pm 0.329$ & $8.37 \pm 11.7$ & $12.2 \pm 12.1$ & $4.27 \pm 5.72$ \\
\hline $\mathrm{Tb}$ & $0.273-0.554$ & $0.278-0.528$ & $0.280-0.540$ & $0.037-0.158$ & $0.039-0.129$ & $0.015-0.153$ & $0.540-5.22$ & $0.360-5.45$ & $<0.500-2.41^{*}$ \\
\hline $\bar{x} \pm \sigma$ & $0.424 \pm 0.111$ & $0.378 \pm 0.082$ & $0.394 \pm 0.101$ & $0.099 \pm 0.049$ & $0.092 \pm 0.037$ & $0.067 \pm 0.046$ & $1.46 \pm 1.68$ & $2.05 \pm 1.83$ & $1.139 \pm 0.721$ \\
\hline Dy & $1.39-2.87$ & $1.45-2.68$ & $1.44-2.66$ & $0.195-0.817$ & $0.205-0.678$ & $0.080-0.787$ & $1.26-24.8$ & $2.53-26.8$ & $1.07-11.8$ \\
\hline $\bar{x} \pm \sigma$ & $2.14 \pm 0.537$ & $1.93 \pm 0.414$ & $1.99 \pm 0.481$ & $0.510 \pm 0.252$ & $0.478 \pm 0.193$ & $0.346 \pm 0.234$ & $6.81 \pm 8.09$ & $10.1 \pm 8.45$ & $4.17 \pm 3.58$ \\
\hline Ho & $0.256-0.555$ & $0.274-0.499$ & $0.269-0.485$ & $0.036-0.162$ & $0.038-0.133$ & $0.014-0.147$ & $<0.500-5.05$ & $0.590-5.55$ & $<0.500-2.11$ \\
\hline $\bar{x} \pm \sigma$ & $0.402 \pm 0.105$ & $0.359 \pm 0.078$ & $0.372 \pm 0.086$ & $0.098 \pm 0.050$ & $0.091 \pm 0.037$ & $0.066 \pm 0.043$ & $1.78 \pm 1.62 *$ & $2.16 \pm 1.65$ & $1.08 \pm 0.598 *$ \\
\hline $\mathrm{Er}$ & $0.727-1.60$ & $0.777-1.39$ & $0.768-1.39$ & $0.099-0.464$ & $0.101-0.375$ & $0.034-0.419$ & $1.13-14.1$ & $1.29-14.4$ & $<0.500-6.79$ \\
\hline
\end{tabular}


Table 1 (continued)

\begin{tabular}{llllllllll}
\hline $\begin{array}{l}\text { Month of } \\
\text { collection }\end{array}$ & April & May & June & April & May & June & April & May & June \\
Parameter & Rhizosphere soils & & Roots & & & Shoots & \\
\hline$\overline{\boldsymbol{x}} \pm \boldsymbol{\sigma}$ & $1.13 \pm 0.295$ & $1.02 \pm 0.208$ & $1.05 \pm 0.246$ & $0.268 \pm 0.144$ & $0.254 \pm 0.107$ & $0.181 \pm 0.122$ & $3.89 \pm 4.59$ & $5.31 \pm 4.62$ & $2.98 \pm 2.17 *$ \\
$\mathrm{Tm}$ & $0.101-0.216$ & $0.108-0.186$ & $0.104-0.187$ & $0.014-0.065$ & $0.014-0.051$ & $0.005-0.058$ & $<0.500-1.73 *$ & $0.210-2.53$ & $<0.500-1.09$ \\
$\overline{\boldsymbol{x}} \pm \boldsymbol{\sigma}$ & $0.151 \pm 0.039$ & $0.140 \pm 0.027$ & $0.142 \pm 0.031$ & $0.037 \pm 0.021$ & $0.034 \pm 0.014$ & $0.025 \pm 0.017$ & $0.968 \pm 0.661$ & $0.960 \pm 0.830$ & $0.609 \pm 0.322^{*}$ \\
$\mathrm{Yb}$ & $0.621-1.35$ & $0.685-1.12$ & $0.637-1.09$ & $0.081-0.362$ & $0.072-0.302$ & $0.029-0.332$ & $0.81-11.6$ & $0.850-13.3$ & $0.550-5.37$ \\
$\overline{\boldsymbol{x}} \pm \boldsymbol{\sigma}$ & $0.937 \pm 0.241$ & $0.849 \pm 0.154$ & $0.859 \pm 0.174$ & $0.213 \pm 0.117$ & $0.200 \pm 0.084$ & $0.143 \pm 0.097$ & $3.33 \pm 3.87$ & $4.87-4.32$ & $1.98 \pm 1.63$ \\
$\mathrm{Lu}$ & $0.098-0.218$ & $0.109-0.177$ & $0.107-0.176$ & $0.012-0.058$ & $0.011-0.047$ & $0.045-0.052$ & $<0.500-2.18$ & $<0.500-2.66$ & $<0.500-1.20$ \\
$\overline{\boldsymbol{x}} \pm \boldsymbol{\sigma}$ & $0.151 \pm 0.039$ & $0.136 \pm 0.024$ & $0.141 \pm 0.027$ & $0.033 \pm 0.019$ & $0.031 \pm 0.013$ & $0.022 \pm 0.015$ & $0.918 \pm 0.712^{*}$ & $1.13 \pm 0.785^{*}$ & $0.636 \pm 0.342^{*}$ \\
\hline $\bar{x}-\boldsymbol{a r i t h}$ & & & & & & & & & \\
\hline
\end{tabular}

$\bar{x}$ - arithmetic mean, $\sigma$ - standard deviation, * - arithmetic mean computed for data above the limit of quantification, $* *$ - results significantly different $(\mathrm{p}<0.05)$ from the others

\section{BAF, TF and salinity factors}

Bioaccumulation factor (BAF) is used to quantify the effectiveness of a plant in the trace elements uptake from soil. The BAF below 0.01 means no accumulation, between 0.01 and 0.1 indicates low accumulation, between 0.1 and 1.0 medium accumulation and above 1.0 high bioaccumulation Aladesanmi et al. 2019; Pachura et al. 2016 and references therein). The BAF of examined metals varied from $<0.001$ to 7.5 and were strongly element and site dependent (Fig. 4A). The lowest values were obtained for REEs $(<0.001-0.03)$ and the highest for $\mathrm{Cd}$ (0.13-7.5). For $\mathrm{Zn}$ and $\mathrm{Cu}$, the BAF values were in the ranges of 0.094-1.03 and 0.07-0.69, respectively, whereas for $\mathrm{Ag}$, $\mathrm{Co}$ and $\mathrm{Pb}$ were as follows: 0.02-0.23, 0.002$0.07,<0.001-0.05$.

The translocation factor (TF) is employed to assess the effectiveness of an element transport from the root to the shoot. For this factor, the values lower than 1 indicate that metals are accumulated by plants but stored in the roots. The values higher that 1 indicate translocation to the aerial parts (Mellem et al. 2009). The TF values, for all the metals examined varied from $<0.001$ to 3.7 , and similar to BAF with the lowest for REE $(<0.001-0.10)$ and the highest for $\mathrm{Cd}$ (0.02-3.7) (Fig. 4B).

The $\mathrm{K} / \mathrm{Na}$ and $\mathrm{Ca} / \mathrm{Na}$ ratios, known as salinity factors were computed to compare the levels of soil and plant salinity. In our study, they varied from 1.8 to 110 , with the lowest values in the roots (mean of 8.3), and from 0.34 to 58 , with the lowest in the shoots (mean of 4.5), respectively (Table 3 of ESM). The mean $\mathrm{Ca} / \mathrm{Na}$ ratio values of the roots and shoots collected in June $(1.9,0.97)$ were up to 7 times lower than those recorded in April $(9.7,5.7)$ and May (5.8, 6.7).

\section{Discussion}

$\mathrm{pH}$ and $\mathrm{Cl}$

Metals may be present in soil solution in three major states, as free (non-complexed) ions, inorganic and organic soluble or insoluble complexes. Their bioavailability depends on a binding capacity of soil and a number of factors, like $\mathrm{pH}$, redox potential, soil texture, clay and organic matter content, occurrence of iron and manganese oxyhydroxides, presence of different anions and cations, and activity of microorganisms (Schlesinger and Bernhardt 2020; Singh et al. 2014). According to the literature, bioavailability of trace metals and element transfer from the soil solution to the root depend on this parameter (Singh et al. 2014). However, no significant correlations were found between the $\mathrm{pH}$ of soil solutions and trace element contents in soils and individual parts of plant.

In soils, chlorine occurs mainly in the form of simple $\mathrm{Cl}^{-}$ions. In the temperate climate zone, soils have a net negative charge, therefore their anion adsorption capacity is low. It is also less efficient in the presence of organic ions which can block anion binding sites (Schlesinger and Bernhardt 2020). Lower concentrations of chlorides in soil solutions (sites $\# 2,3$ ) corresponded to higher ones in the roots and shoots, but these correlations were not significant $(p>0.05)$. Between April and June, a gradual increase 


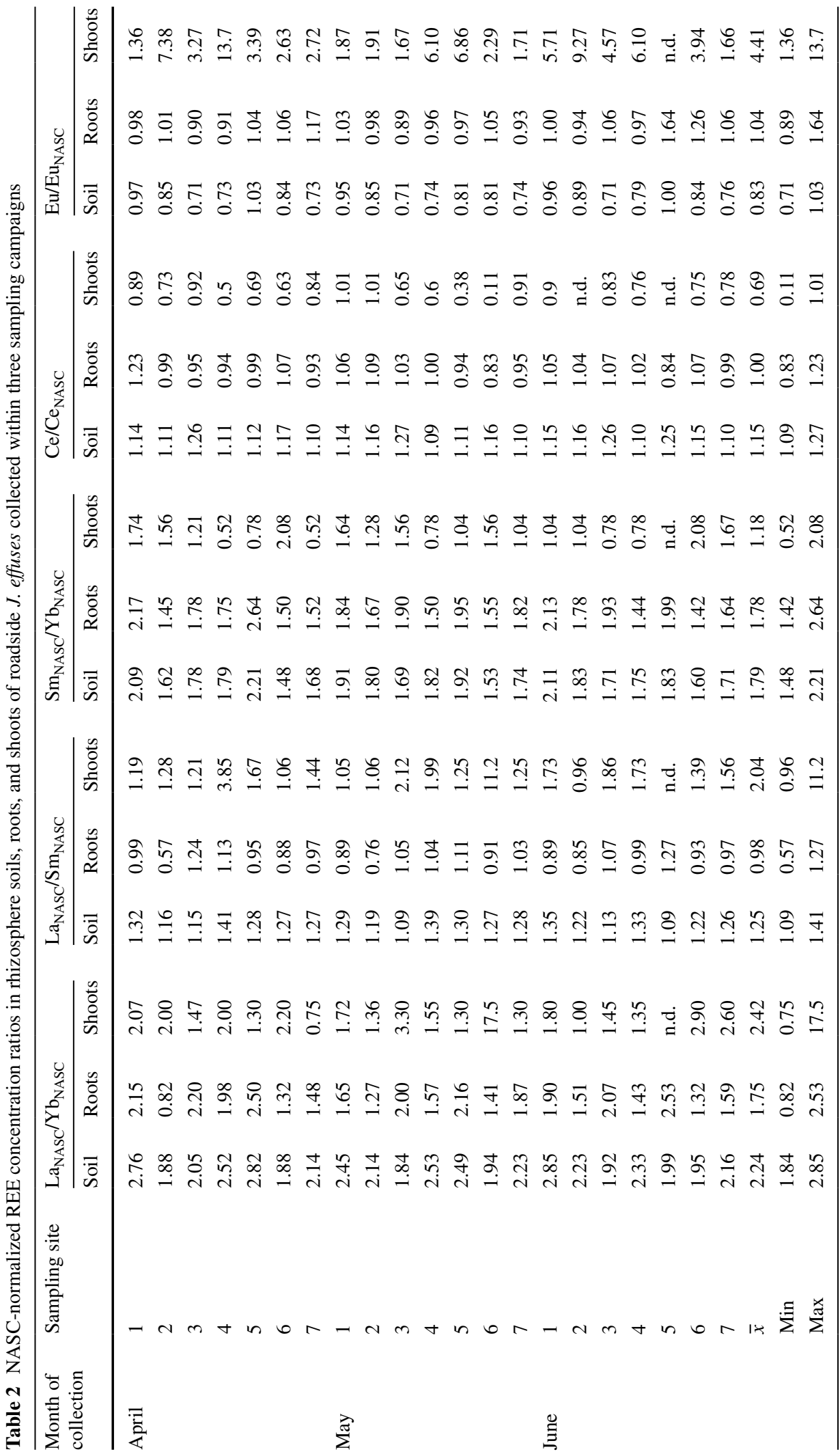




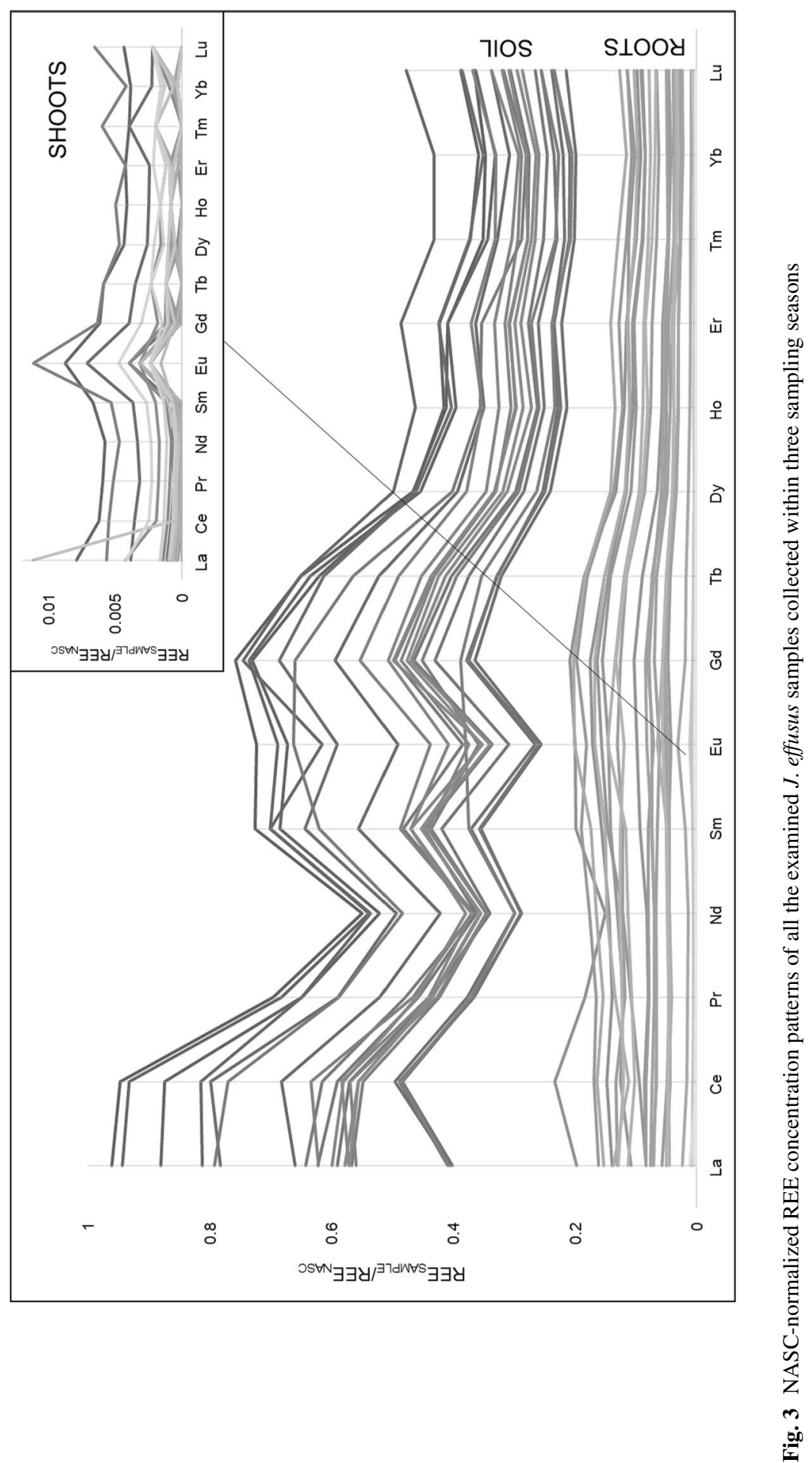



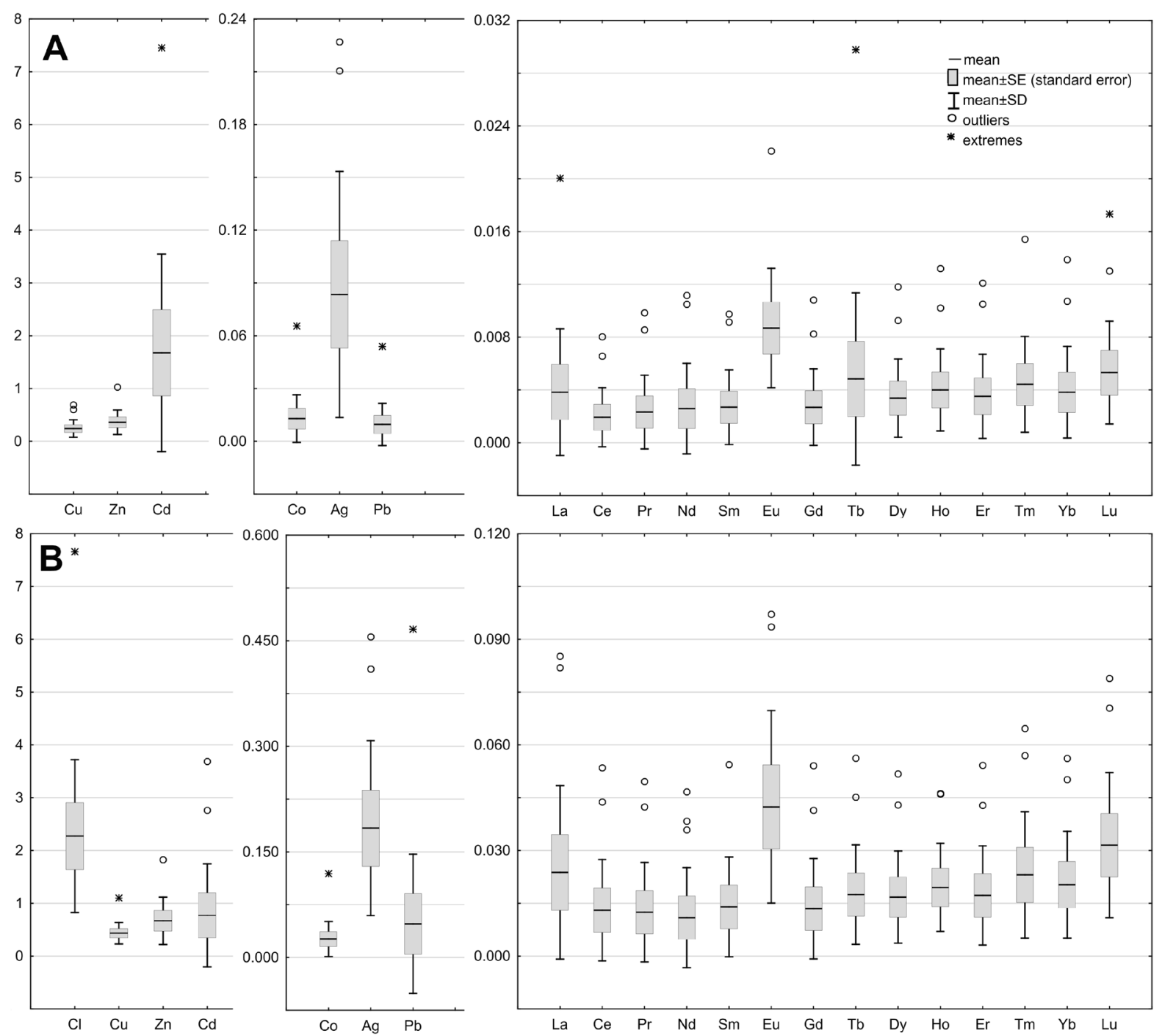

Fig. 4 Box-plotsof: A - bioaccumulation (BAF) and B - translocation (TF) factors computed for J. effusus samples

in $\mathrm{Cl}^{-}$content was observed in the shoots and roots from site 1 and in the shoots from sites 3 and 5, but only in samples from the first site this increase correlated with a gradual decrease in soils. Despite the gradual increase, the $\mathrm{Cl}^{-}$content of the shoots from site 5, was still the lowest in comparison to its content in the shoots from the other sites. It can be explained by the fact that at this location (Fig. 1), samples were taken from a roadside open space, about $3 \mathrm{~m}$ from the road shoulder.

Chloride ions supports plant growth, therefore, it dominates in above ground organs (shoots, leaves) and its accumulation can be limited only in salinity sensitive plants. Differences $(p<0.05)$ in $\mathrm{Cl}^{-}$concentrations between various parts of the plant are not surprising and have been noted by several authors (White and Broadley 2001 and references therein). The distribution sequence obtained (shoots $>$ roots) backs up previous findings (Chen et al. 2010). About $45 \%$ lower concentrations in the roots in comparison to the shoots, and the average translocation factor (TF) of 2.3 (Fig. 4B), clearly indicate that $\mathrm{Cl}^{-}$is easily transported from the roots to the shoots. According to the literature, the average $\mathrm{Cl}^{-}$content in plants varies from 1000 to $20,000 \mathrm{mg} \bullet \mathrm{kg}^{-1}$, but the plant requirement for optimal growth is much lower, in 
the range of 200 to $400 \mathrm{mg} \cdot \mathrm{kg}^{-1}$ (Chen et al. 2010; Wang et al. 2020). The obtained values (Table 1) are in the medium range, but are higher than the optimum values recorded for plants of the temperate climate zone, e.g., corn (10-20 mg• $\left.\mathrm{kg}^{-1}\right)$, sugar beet $\left(100-200 \mathrm{mg} \cdot \mathrm{kg}^{-1}\right)$ and higher than concentrations found in the shoots of $J$ effuses $\left(2914 \mathrm{mg} \mathrm{kg}^{-1}\right.$ ) collected from sites located in the HCMs (Krzciuk and Gałuszka 2019), but not exposed to de-icing salts (unpublished data). The reason for this is the exposure of examined plants to de-icing agents, which are an additional source of $\mathrm{Cl}^{-}$.

\section{$\mathrm{Cd}, \mathrm{Co}, \mathrm{Cu}$ and $\mathrm{Zn}$}

Formation of chloride complexes in soils changes the mobility of trace metals and their availability to plants (vide 1 section). Ghallab et al. (2007) and Weggler et al. (2004) noted that the addition of chlorides to different types of soil increased $\mathrm{Cd}$ concentrations in plants due to formation of $\mathrm{CdCl}_{\mathrm{n}}{ }^{(\mathrm{n}-2)} \mathrm{com}-$ plexes. Further research (Cheng et al. 2018) gave the opposite results. The authors found that the addition of $\mathrm{NaCl}$ reduces $\mathrm{Cd}$ accumulation in Carpobrotus rossii shoots and inhibits the Cd uptake by roots and its translocation from the root to the shoot. The order of the average Cd contents: $\mathrm{Cd}_{\text {roots }}>\mathrm{Cd}_{\text {shoots }}>\mathrm{Cd}_{\text {soils }}$ confirms the previous findings (Benavides et al. 2005) that $\mathrm{Cd}$ easily penetrates the roots and then passes to the aboveground parts. The mean value recorded in the shoots $\left(0.960 \mathrm{mg} \cdot \mathrm{kg}^{-1}\right)$ was higher than that noted in Juncus sp. $\left(0.674 \mathrm{mg} \cdot \mathrm{kg}^{-1}\right)$ collected from the vicinity of saline Maharlu Lake in Iran (Zare et al. 2020), but lower than in the J. effusus shoots from the Holy Cross Mountains $\left(2.35 \mathrm{mg} \bullet \mathrm{kg}^{-1}\right.$ ) (Krzciuk and Gałuszka 2019). The shoots taken in June were depleted in $\mathrm{Cd}$ in comparison to those from April and May and this difference is significant $(p<0.05)$ (Table 1). This may indicate three aspects: (i) activation of mechanisms that limit the entry of $\mathrm{Cd}$ from the root to the xylem during the growing season as evidenced by Lux et al. (2011) (positive correlations were recorded in May and June for the $\mathrm{Cd}_{\text {roots }}-\mathrm{Cd}_{\text {soils }}$ pair; Table 2 of ESM), (ii) reduction in Cd contents as an effect of dilution due to an increase in plant biomass, or (iii) inhibition of $\mathrm{Cd}$ accumulation in the presence of higher $\mathrm{Cl}^{-}$contents. The reduction in $\mathrm{Cd}$, but also in $\mathrm{Pb}, \mathrm{Co}$ and $\mathrm{Zn}$ contents observed from May to June was not recorded in our previous studies (Krzciuk and Gałuszka 2019). In contrary to our results, samples of J. effusus collected monthly from May to November within the HCM area showed an increase in $\mathrm{Co}$ and $\mathrm{Zn}$, and in some cases in $\mathrm{Pb}$. The reduction was noted for $\mathrm{Cd}$ and $\mathrm{Ag}$. In both studies, the concentration of $\mathrm{Cu}$ was higher in the shoots from June than in the shoots from May. Considering the inhibition of $\mathrm{Cd}$ uptake by $\mathrm{Cl}^{-}$ions, in April and May, the concentrations of $\mathrm{Cd}$ in the roots and soils were positively correlated with the $\mathrm{Cl}^{-}$content in the rhizosphere soil solutions. At that time, this correlation was negative for the shoots. In June these relationships changed to positive for the shoots and negative for the roots and soils. The observed change suggests that chlorides may affect $\mathrm{Cd}$ availability, but this process is not observed before the growing season when the biomass growth of plant is negligible (Lux et al. 2011). $\mathrm{Zn}, \mathrm{Cu}$ and Co form similar complexes with chlorides as $\mathrm{Cd}$, but their behavior in the soil differs due to different affinity to $\mathrm{Cl}^{-}$ions and role in plants (Du et al. 2020; Ghallab et al. 2007; Usman et al. 2005). Both $\mathrm{Zn}$ and $\mathrm{Cu}$ do not change their form in the presence of chloride ions and occur mainly as $\mathrm{M}^{2+}$ ions. Complex compounds $\left(\mathrm{MCl}_{\mathrm{n}}{ }^{(\mathrm{n}-2)}\right)$ account for about 2\% (Usman et al. 2005). In April and May the content of $\mathrm{Zn}$ in the shoots was slightly and negatively, but insignificantly, correlated with the content of $\mathrm{Cl}^{-}$in the soils, while in June this correlation was positive. The lack of significant correlations between $\mathrm{Zn}$ and $\mathrm{Cl}$ (Table 2 of ESM), confirms that $\mathrm{Cl}^{-}$ions, even in higher concentrations, do not affect the accumulation of this metal, which in the soils occurs mainly as a divalent ion or a complex with organic ligands (Matthews et al. 2004; Tsonev and Lidon 2012).

The concentration order of $\mathrm{Zn}$ was as follows: soils $>$ roots $>$ shoots $\quad(p<0.05)$ Concentrations recorded in the shoots collected in April and May were almost twice as high as those in June $(p<0.05)$ (Table 1). This suggests that $\mathrm{Zn}$ is taken up by the $J$. effusus shoots more effectively at the beginning of the growing season. The content of $\mathrm{Zn}$ in the roots and soils was positively and significantly correlated with the content of $\mathrm{Cd}$ in the same samples (Table 2 of ESM). Such correlations were found regardless of the time of sampling. The negative correlations obtained for the $\mathrm{Zn}_{\text {soils }}-\mathrm{Cd}_{\text {shoots }}$ pair may indicate inhibition of $\mathrm{Cd}$ uptake and its translocation in the presence of $\mathrm{Zn}$ (Du et al. 2020. 
Concentrations of $\mathrm{Cu}$ were typical for samples from uncontaminated sites (Table 1). Regardless of the time of sampling, we found a strong and positive correlation between $\mathrm{Cu}$ and $\mathrm{Cd}$ in the shoots. According to the literature (Murtaza et al. 2017), the presence of $\mathrm{Cu}$ supresses the $\mathrm{Cd}$ uptake. The synergistic effect for those two metals can be observed, but only at low metal concentrations (Mwamba et al. 2016). Significant and negative correlations between $\mathrm{Cu}_{\text {shoots/roots }}-\mathrm{Cl}_{\text {soils }}$ were found in June. Such negative, although insignificant, relationships were also noted for Co (Table 2 of ESM). This similarity can be explained by the fact that these two metals are known to alleviate salinity stress (Hejazi Mehrizi et al. 2012; Yadav et al. 2020), which in the case of our study is due to the presence of higher $\mathrm{Cl}^{-}$concentrations from de-icing salts. Co belongs to microelements responsible for the plant growth, metabolism, and development of root nodules (Nagajyoti et al. 2010). In our study, the concentrations in the shoots were even 400 times lower than those in the soils and 130 times lower than in the roots. These results are in complete agreement with Kosiorek and Wyszkowski (2020) and further support the concept of the presence of Co tolerance mechanism (Mahey et al. 2020). We also found higher concentrations $(p>0.05)$ in May and June than in April which may result the Co release from insoluble forms by biologically produced chelating ligands during the growing season (Palit et al. 1994).

\section{$\mathrm{Ag}$ and $\mathrm{Pb}$}

Silver and lead belong to elements which in the presence of chloride ions form both insoluble and stable salts $\left(\mathrm{AgCl} ; \mathrm{PbCl}_{2}\right)$ and soluble complexes. We did not find statistically significant correlations between $\mathrm{Ag}$ and $\mathrm{Cl}$ (Table 2 of ESM), even though a characteristic trend was observed. Regardless of the time of sampling, concentration of $\mathrm{Ag}$ in the shoots and roots corresponded to $\mathrm{Cl}^{-}$content in roots, while an opposite relationship was noted for $\mathrm{Cl}^{-}$content in soil solutions. This suggests that the presence of chlorides in soil solutions may reduce $\mathrm{Ag}$ uptake by plants (Fortin and Campbell 2000 and references therein), especially at low concentrations of $\mathrm{Ag}$ (CruzadoTafur et al. 2021).

The concentration order of $\mathrm{Ag}$ was as follows: rhizosphere soils $>$ roots $>>$ shoots with significant differences between the shoots and the other samples $(p<0.05)$. The above order is consistent with our previous findings (Krzciuk and Gałuszka 2019), but in this study, the concentration of $\mathrm{Ag}$ in the shoots was almost nine times lower than in the roots, whereas the shoots and roots of $J$. effusus from the Holy Cross Mountains did not reveal such a big difference (results compared for samples collected in May) (Krzciuk and Gałuszka 2019). This may confirm the relationship related to reduced $\mathrm{Ag}$ uptake in the presence of higher $\mathrm{Cl}^{-}$concentrations. According to the literature, the amount of $\mathrm{Ag}$ absorbed by plants depends on its concentration in soils (Cruzado-Tafur et al. 2021 and references therein), but in our study $\mathrm{Ag}$ concentrations in the shoots were on average 17 times lower than those in the soils. The similar relationship was noted by Tyler and Olsson (2001) for $A$. capillaris planted in Ag-saturated soils. The authors obtained much lower concentrations in the aboveground parts than in the soils and roots. This phenomena can be explained by the fact that plant roots act as a barrier against many less essential elements, but the influence of $\mathrm{Cl}^{-}$on this process needs further investigations.

The possible co-occurrence of $\mathrm{Ag}, \mathrm{Cd}, \mathrm{Cu}$ and $\mathrm{Pb}$ in the shoots collected at the beginning and during the growing season (May and June), as shown by the correlation coefficients (Table 2 of ESM), is due to the fact that these metal ions $\left(\mathrm{Ag}^{+}, \mathrm{Cu}^{2+}, \mathrm{Cd}^{2+}, \mathrm{Pb}^{2+}\right)$ activate the biosynthesis of phytochelatins - trace metal binding peptides (Schmoger et al. 2000).

Significant and negative correlations obtained for the $\mathrm{Pb}_{\text {roots/soils }}-\mathrm{Cl}_{\text {soils/shoots }}$ pairs (Table 2 of ESM) suggest that $\mathrm{Pb}$ may limit the bioaccumulation of $\mathrm{Cl}^{-}$, especially during the growing season. According to the literature data, the addition of $\mathrm{Cl}^{-}$ions to the soil solution changes a process of $\mathrm{Pb}$ accumulation. This change depends on the $\mathrm{pH}$ and chloride concentrations (different types of complexes are formed) and a low concentration of $\mathrm{NaCl}$ inhibits $\mathrm{Pb}$ accumulation (Xiong and Feng 2001). However, the efficiency of this process is also dependent on the soil type (Usman et al. 2005).

The mean values of $\mathrm{Pb}$ in the shoots and roots were higher than those in J. effusus from the Holy Cross Mts. (Gałuszka et al. 2015; Krzciuk and Gałuszka 2019). Only in May the significant correlations were found between the content of this metal in the samples analyzed. 


\section{REEs}

According to the literature, REEs form chloride complexes, but the efficiency of this process and stability of compounds depend on several factors, including temperature (Gammons et al. 1996). Stability of REE chloride complexes increases with temperature which in our study can be confirmed by correlations with $\mathrm{Cl}^{-}$recorded in the shoots from June (Table 2 of ESM). The most interesting positive correlations $(p<0.05)$ were recorded in the samples taken in May between the following pairs of elements: Ag-REE, Cd-REE, and Co-REE. Such correlations have not been found by Krzciuk and Gałuszka (2019), which may suggest a possible chloride role in the process of metal accumulation, however, in-depth investigation is needed.

The typical REE concentrations in soils vary from 10 to $100 \mathrm{mg} \cdot \mathrm{kg}^{-1}$ (Dołęgowska and Migaszewski 2013), whereas in plants they are much lower, ranging from $<0.05$ to $2.58 \mathrm{mg} \cdot \mathrm{kg}^{-1}$ (Hu et al. 2013). The same relationship has been observed in our study (Table 1). La and Ce predominated in all the samples examined. The concentration order in the shoots $\quad(\mathrm{Ce}>\mathrm{La}>\mathrm{Nd}>\mathrm{Pr}>\mathrm{Sm}>\mathrm{Gd}>\mathrm{Dy}>\mathrm{Eu}>\mathrm{Er}>\mathrm{Y}$ $\mathrm{b}>\mathrm{Ho}>\mathrm{Tb}>\mathrm{Lu}>\mathrm{Tm}$ ) differed from that in the roots and rhizosphere soils, which is like total concentrations in the Earth's crust $(\mathrm{Ce}>\mathrm{Nd}>\mathrm{La}>\mathrm{Pr}>\mathrm{Sm}>\mathrm{Gd}$ $>\mathrm{Dy}>\mathrm{Er}>\mathrm{Yb}>\mathrm{Eu}>\mathrm{Ho}>\mathrm{Tb}>\mathrm{Lu}>\mathrm{Tm}$ ) (Greenwood and Earnshaw 1997). The calculated $\mathrm{La}_{\mathrm{NASC}} / \mathrm{Yb}_{\mathrm{NASC}}$, $\mathrm{La}_{\text {NASC }} / \mathrm{Sm}_{\mathrm{NASC}}$ and $\mathrm{Sm}_{\text {NASC }} / \mathrm{Yb}_{\text {NASC }}$ ratios (Table 3 ) indicate a characteristic change in element enrichment in the samples examined. The rhizosphere soils are enriched in light rare elements (LREE), the roots in medium rare earth elements (MREE), while both light and in some cases heavy rare elements (HREE) prevail in the shoots. The observed predominance of LREE over HREE in the soils has been noted by several authors (Brioschi et al. 2013; Wang et al. 2005) and relates to the LREE higher mobility in this matrix. The values of $\mathrm{La}_{\mathrm{NASC}} / \mathrm{Sm}_{\mathrm{NASC}}$ and $\mathrm{Sm}_{\mathrm{NASC}}$ $\mathrm{Yb}_{\text {NASC }}$ ratios obtained for the roots point to preferential accumulation of MREE by this part of the plant species (Ding et al. 2005; Brito et al. 2020), whereas the possible translocation of HREE from the roots to the shoots may be associated with specific organic complexation in xylem vessels during the accumulation process (Ding et al. 2005). A characteristic change in shape of the REE-normalized patterns (Fig. 3) is in line with the previous findings (Dołęgowska and Migaszewski 2013; Krzciuk and Gałuszka 2020). The suppression in the roots of the soil-occurring $\mathrm{Ce}(+)$ and Eu (-) anomalies (Fig. 3; Table 2) and their subsequent enhancement in the shoots $(\mathrm{Ce}(-), \mathrm{Eu}(+))$ is related to the change in the redox conditions within the root zone of J. effusus.

BAF, TF and salinity factors

The lowest BAF values indicating a lack of accumulation were obtained for REEs and for Co. These values show a good correlation with those documented by Krzciuk and Gałuszka (2019) and indicate that transfer of these metals to the shoots of $J$. effusus is limited. $\mathrm{Pb}$ shows low accumulation, while $\mathrm{Cu}, \mathrm{Zn}$ and $\mathrm{Ag}$ the medium one. The BAF values of $\mathrm{Cd}$ point to medium and high accumulation, which does not support the previous research in this area (Krzciuk and Gałuszka 2019) and is scarce in nonhyperaccumulative plants. In most cases, cadmium bioaccumulation factors found in the literature pinpoint to low and medium accumulation (Aladesanmi et al. 2019). Higher values (0.4 to 5.8) are recorded for plants growing on soils contaminated with this metal (Mganga 2014; Retamal-Salgado et al. 2017) or for hyperaccumulative plants used in remediation of Cd-polluted sites ( $\mathrm{Li}$ et al. 2018). These unexpected results may be due to the occurrence of higher $\mathrm{Cl}^{-}$concentrations (from de-icing salts), and are confirmed by the statistically significant correlation between the BAF of $\mathrm{Cd}$ and $\mathrm{Cl}^{-}$content in the $J$. effusus roots. The BAF of $\mathrm{Cd}$ was also correlated with the BAF of $\mathrm{Cu}, \mathrm{Zn}$ and $\mathrm{Ag}$, which confirms their cooccurrence in the shoots at different levels (Table 1) (Schmoger et al. 2000). Taking under consideration differences between the sampling seasons, the BAF of $\mathrm{Zn}$ from April and May differed significantly from the BAF noted in June, when the lowest values were recorded. In regards to $\mathrm{Ag}$, such differences occurred during all three sampling seasons with the highest BAF values in April. Depending on the sampling location, the highest BAF values were recorded in the samples from sites \#2 and 3, but no correlation was found between these values and $\mathrm{Cl}^{-}$content in samples from these sites.

The TF values obtained are strongly element and dependent (Fig. 4b). The lowest values were recorded for REEs, while higher than 1.0 were obtained for 
$\mathrm{Zn}$ and $\mathrm{Cd}$. These findings are in good agreement with the results of Krzciuk and Gałuszka (2019). It is worth noting that the TF of $\mathrm{Eu}, \mathrm{Ho}, \mathrm{Er}, \mathrm{Yb}$ and $\mathrm{Lu}$ were negatively correlated $(p<0.05)$ with the content of $\mathrm{Cl}^{-}$in the $J$. effusus roots.

The K/Na ratios (Table 3 of ESM) are comparable with those obtained for urban soils and roadside tree leaves collected in Kielce in 2010 , while the $\mathrm{Ca} / \mathrm{Na}$ ratios are much lower than those from 2010 (Gałuszka et al. 2011). A decrease in these ratios indicates an increase in salinity, caused by elevated sodium concentrations from additional source of this metal, e.g., de-icing salts. The variability of the computed ratios is related to the type of sample, sampling time and site location. In the roots, the lowest K/Na mean value was recorded for samples collected in June. Regardless of sampling time, for both shoots and soils, the $\mathrm{K} / \mathrm{Na}$ ratio was significantly higher. In general, the $\mathrm{Ca} / \mathrm{Na}$ ratio of soils was higher than that of roots and shoots. The exception is the soil from site 5 , which is in complete agreement with the lowest $\mathrm{Cl}^{-}$concentrations in samples from this location (Table 2 of ESM). It is interesting to note that the differences between the following pairs: $\mathrm{K} / \mathrm{Na}_{\text {roots(April/May) }}-\mathrm{K} / \mathrm{Na}_{\text {roots(June); }}$; $\mathrm{Ca} / \mathrm{Na}_{\text {tissues(May) }}-\mathrm{Ca} / \mathrm{Na}_{\text {tissues(June) }}$ were statistically significant. Both ratios indicate enhanced accumulation of sodium at the beginning of the growing season.

\section{Conclusions}

The presence of chlorides in soils, e.g., from de-icing salts, leads to formation of complex compounds with various trace metals. This process changes metal mobility making them accessible to plants. The assessment of the potential effect of de-icing agents on metal bioavailability to roadside plants in their natural habitats is more problematic than in the laboratory-based conditions. This process depends on the type of element, soil metal concentrations and interactions, and individual plant features.

The computed salinity factors indicate risen concentrations of $\mathrm{Na}$ and its origin from de-icing salt. The comparison of $\mathrm{Cl}^{-}$concentrations in the rhizosphere soil, roots and shoots of roadside $J$. effusus showed that $\mathrm{Cl}^{-}$ions are easily transported to the aboveground parts hence its concentrations were the highest in the shoots and up to 8 times higher compared to the roots. The concentrations of $\mathrm{Cl}^{-}$in the shoots were up to 3 times higher than those in the shoots of $J$. effusus collected from the sites not exposed to de-icing agents. The concentration order of examined elements (excluding Cd) was: rhizosphere soils $>$ roots $>$ shoots, indicating their controlled uptake. Almost reversed (roots $>$ shoots $>$ rhizosphere soils) for $\mathrm{Cd}$ may suggest that this metal is much easier taken up by the roots and transported to the shoots, however, this process is inhibited in the growing season. The computed BAF and TF values showed that $\mathrm{Cd}$ was taken up most easily, followed by $\mathrm{Zn}$ and $\mathrm{Cu}$. The bioaccumulation and translocation of $\mathrm{Ag}, \mathrm{Co}, \mathrm{Pb}$ and REEs were very low. This suggests that at a low metal concentration, chlorides may reduce the efficiency of these processes. However, confirmation of the potential role of $\mathrm{Cl}^{-}$ions in these processes requires further research.

Strong negative correlations found in June between $\mathrm{Cu}$ and $\mathrm{Co}$ in the shoots/roots and $\mathrm{Cl}^{-}$in the rhizosphere soils may suggest their role in salinity stress alleviation due to the presence of an additional source of $\mathrm{Cl}^{-}$, i.e. de-icing salts. The MREE exhibited higher concentrations than LREE and HREE in the roots as opposed to soils and the shoots that showed LREE enrichment. Significant correlations between some REEs and $\mathrm{Cl}^{-}$recorded for the shoots collected in June may indicate the influence of temperature on the stability of REE chloride complexes, however, it is the first insight into this issue which needs more studies. As in the previous studies, we noted the characteristic change in the $\mathrm{Ce}$ and $\mathrm{Eu}$ anomalies observed in the soil-root-shoot system, i.e., from $\mathrm{Ce}(+)$ and $\mathrm{Eu}$ $(-)$ in the soils to $\mathrm{Ce}(-)$ and $\mathrm{Eu}(+)$ in the shoots. This relation resulted from $J$. effusus features and changes in the redox conditions within the root zone of this plant species.

Author contributions D.S. conceptualization, methodology, fieldworks, sample preparation, chemical analyses, writingoriginal draft preparation; G.A. chemical analyses, writingreviewing and editing; M.Z.M. writing-reviewing and editing: K.K. conceptualization, fieldworks, sample preparation, writing-reviewing and editing.

\section{Declarations}

Conflict of interest The authors declare that they have no known competing financial interests or personal relationships 
that could have appeared to influence the work reported in this paper.

Open Access This article is licensed under a Creative Commons Attribution 4.0 International License, which permits use, sharing, adaptation, distribution and reproduction in any medium or format, as long as you give appropriate credit to the original author(s) and the source, provide a link to the Creative Commons licence, and indicate if changes were made. The images or other third party material in this article are included in the article's Creative Commons licence, unless indicated otherwise in a credit line to the material. If material is not included in the article's Creative Commons licence and your intended use is not permitted by statutory regulation or exceeds the permitted use, you will need to obtain permission directly from the copyright holder. To view a copy of this licence, visit http://creativecommons.org/licenses/by/4.0/.

\section{References}

Aladesanmi OT, Oroboade JG, Osisiogu CP, Osewole AO (2019) Bioaccumulation factor of selected heavy metals in Zea mays. J Heal Pollut 9:191207. https://doi.org/10.5696/ 2156-9614-9.24.191207

Backström M, Karlsson S, Backman L, Folkeson L, Lind B (2004) Mobilisation of heavy metals by deicing salts in a roadside environment. Water Res 38:720-732. https://doi. org/10.1016/j.watres.2003.11.006

Bau M, Schmidt K, Pack A, Bendel V, Kraemer D (2018) The European Shale: An improved data set for normalisation of rare earth element and yttrium concentrations in environmental and biological samples from Europe. Appl Geochem 90:142-149. https://doi.org/10.1016/j.apgeo chem.2018.01.008

Benavides MP, Gallego SM, Tomaro ML (2005) Cadmium toxicity in plants. Braz J Plant Physiol 17:21-34. https:// doi.org/10.1590/S1677-04202005000100003

Bouldin JL, Farris JL, Moore MT, Smith S Jr, Cooper CM (2006) Hydroponic uptake of atrazine and lambda-cyhalothrin in Juncus effusus and Ludwigia peploides. Chemosphere 65:1049-1057. https://doi.org/10.1016/j.chemo sphere.2006.03.031

Brioschi L, Steinmann M, Lucot E, Pierret MC, Stille P, Prunier J, Badot PM (2013) Transfer of rare earth elements (REE) from natural soil to plant systems: Implications for the environmental availability of anthropogenic REE. Plant Soil 366:143-163. https://doi.org/10.1007/ s11104-012-1407-0

Brito P, Mil-Homens M, Caçador I, Caetano M (2020) Changes in REE fractionation induced by the halophyte plant Halimione portulacoides, from SW European salt marshes. Mar Chem 223:103805. https://doi.org/10.1016/j.march em.2020.103805

Chen W, He ZL, Yang XE, Mishra S, Stoffella PJ (2010) Chlorine nutrition of higher plants: Progress and perspectives. J Plant Nutr 33:943-952. https://doi.org/10.1080/01904 160903242417

Cheng M, Wang A, Liu Z, Gendall AR, Rochfort S, Tang C (2018) Sodium chloride decreases cadmium accumulation and changes the response of metabolites to cadmium stress in the halophyte Carpobrotus rossii. Ann Bot 122:373-385. https://doi.org/10.1093/aob/mcy077

Cruzado-Tafur E, Bierla K, Torró L, Szpunar J (2021) Accumulation of $\mathrm{As}, \mathrm{Ag}, \mathrm{Cd}, \mathrm{Cu}, \mathrm{Pb}$, and $\mathrm{Zn}$ by native plants growing in soils contaminated by mining environmental liabilities in the Peruvian Andes. Plants 10:1-23. https:// doi.org/10.3390/plants10020241

Czerniawska-Kusza I, Kusza G, Duz M (2004) Effect of deicing salts on urban soils and health status of roadside trees in the Opole Region. Environ Toxicol 19:296-301. https:// doi.org/10.1002/tox.20037

Devitt DA, Wright L, Landau F, Apodaca L (2014) Deicing Salts; Assessing distribution, ion accumulation in plants and the response of plants to different loading rates and salt mixtures. Environ Nat Resour J 4:73-93. https://doi. org/10.5539/enrr.v4n1p73

Ding S, Liang T, Yan J, Zhang Z, Huang Z, Xie Y (2007) Fractionations of rare earth elements in plants and their conceptive model. Sci China Ser C Life Sci 50:47-55. https:// doi.org/10.1007/s11427-007-2040-7

Ding SM, Liang T, Zhang CS, Yan JC, Zhang ZL (2005) Accumulation and fractionation of rare earth elements (REEs) in wheat: Controlled by phosphate precipitation, cell wall absorption and solution complexation. J Exp Bot 56:2765-2775. https://doi.org/10.1093/jxb/eri270

Dołęgowska S, Gałuszka A, Migaszewski ZM (2021) Significance of the long-term biomonitoring studies for understanding the impact of pollutants on the environment based on a synthesis of 25-year biomonitoring in the Holy Cross Mountains, Poland. Environ Sci Pollut Res 28:10413-10435

Dołęgowska S, Gałuszka A, Migaszewski ZM (2017) An impact of moss sample cleaning on uncertainty of analytical measurement and pattern profiles of rare earth elements. Chemosphere 188:190-198. https://doi.org/10. 1016/j.chemosphere.2017.08.161

Dołęgowska S, Migaszewski ZM (2013) Anomalous concentrations of rare earth elements in the moss-soil system from south-central Poland. Environ Pollut 178:33-40. https://doi.org/10.1016/j.envpol.2013.02.024

Du J, Zeng J, Ming X, He Q, Tao Q, Jiang M, Gao S, Li X, Lei T, Pan Y, Chen Q, Liu S, Yu X (2020) The presence of zinc reduced cadmium uptake and translocation in Cosmos bipinnatus seedlings under cadmium/zinc combined stress. Plant Physiol Biochem 151:223-232. https://doi. org/10.1016/j.plaphy.2020.03.019

Fortin C, Campbell PGC (2000) Silver uptake by the green alga Chlamydomonas reinhardtii in relation to chemical speciation: influence od chloride. Environ Toxicol Chem 19:2769-2778. https://doi.org/10.1002/etc.5620191123

Gałuszka A, Krzciuk K, Migaszewski ZM (2015) A new twostep screening method for prospecting of trace element accumulating plants. Int J Environ Sci Technol 12:30713078. https://doi.org/10.1007/s13762-014-0719-4

Gałuszka A, Migaszewski ZM, Podlaski R, Dołęgowska S, Michalik A (2011) The influence of chloride deicers on mineral nutrition and the health status of roadside trees in the city of Kielce, Poland. Environ Monit Assess 176:451-464. https://doi.org/10.1007/s10661-010-1596-Z 
Gammons CH, Wood SA, Williams-Jones AE (1996) The aqueous geochemistry of the rare earth elements and yttrium: VI. Stability of neodymium chloride complexes from 25 to $300^{\circ} \mathrm{C}$. Geochim Cosmochim Acta 60:46154630. https://doi.org/10.1016/S0016-7037(96)00262-1

Ghallab A, Rabie A, Usman A (2007) Effect of sodium chloride-induced salinity on phyto-availability and speciation of Cd in soil solution. Water Air Soil Pollut 185:43-51. https://doi.org/10.1007/s11270-007-9424-y

Greenwood NN, Earnshaw A (1997) Chemistry of the Elements, 2nd edn. Butterworth-Heinemann, Oxford

Hejazi Mehrizi M, Shariatmadari H, Khoshgoftarmanesh AH, Dehghani F (2012) Copper effects on growth, lipid peroxidation, and total phenolic content of rosemary leaves under salinity stress. J Agric Sci Technol 14:205-212

Hu Z, Sparovek G, Haneklaus S, Schnug E (2013) Rare earth elements. In: Encyclopedia of Environmental Management. Taylor and Francis, New York

Kosiorek M, Wyszkowski M (2020) Remediation of cobaltcontaminated soil using manure, clay, charcoal, zeolite, calcium oxide, main crop (Hordeum vulgare L.), and after-crop (Synapis alba L.). Minerals 10:499. https://doi. org/10.3390/min10050429

Kovacheva P, Djingova R, Kuleff I (2000) On the representative sampling of plants for multielement analysis. Phytol Balc 6:90-102

Krzciuk K, Gałuszka A (2019) Seasonal changes in concentrations of trace elements and rare earth elements in shoot samples of Juncus effusus L. collected from natural habitats in the Holy Cross Mountains, south-central Poland. Chemosphere 219:954-960. https://doi.org/10.1016/j. chemosphere.2018.12.062

Krzciuk K, Gałuszka A (2020) Presence and possible origin of positive Eu anomaly in shoot samples of Juncus effusus L. J Trace Elem Med Biol 58:126432. https://doi.org/10. 1016/j.jtemb.2019.126432

Langdon KA, McLaughlin MJ, Kirby JK, Merrington G (2015) Influence of soil properties and soil leaching on the toxicity of ionic silver to plants. Environ Toxicol 34:25032512. https://doi.org/10.1002/etc.3067

Loell M, Albrecht C, Felix-Henningsen P (2011) Rare earth elements and relation between their potential bioavailability and soil properties, Nidda catchment (Central Germany). Plant Soil 349:303-317. https://doi.org/10.1007/ s11104-011-0875-y

Li Q, Cai S, Mo C, Chu B, Peng L, Yang F (2010) Toxic effects of heavy metals and their accumulation in vegetables grown in a saline soil. Ecotoxicol Environ Saf 73:84-88. https://doi.org/10.1016/j.ecoenv.2009.09.002

Li Y, Liu K, Wang Y, Zhou Z, Chen C, Ye P, Yu F (2018) Improvement of cadmium phytoremediation by Centella asiatica L. after soil inoculation with cadmium-resistant Enterobacter sp. FM-1. Chemosphere 202:280-288. https://doi.org/10.1016/j.chemosphere.2018.03.097

Liang T, Ding S, Song W, Chong Z, Zhang C, Li H (2008) A review of fractionations of rare earth elements in plants. J Rare Earths 26:7-15. https://doi.org/10.1016/S10020721(08)60027-7

Lux A, Martinka M, Vaculík M, White PJ (2011) Root responses to cadmium in the rhizosphere: A review. J Exp Bot 62:21-37. https://doi.org/10.1093/jxb/erq281
Mahey S, Kumar R, Sharma M, Kumar V, Bhardwaj R (2020) A critical review on toxicity of cobalt and its bioremediation strategies. SN Appl Sci 2:1279. https://doi.org/10. 1007/s42452-020-3020-9

Matthews DJ, Moran BM, Otte ML (2004) Zinc tolerance, uptake and accumulation in the wetland plants Eriophorum angustifolium, Juncus effusus, and Juncus articularus. Wetlands 24:859-869

Mellem JJ, Baijnath H, Odhav B (2009) Translocation and accumulation of $\mathrm{Cr}, \mathrm{Hg}, \mathrm{As}, \mathrm{Pb}, \mathrm{Cu}$ and $\mathrm{Ni}$ by Amaranthus dubius (Amaranthaceae) from contaminated sites. J Environ Sci Heal-Part A Toxic/Hazardous Subst Environ Eng 44:568-575. https://doi.org/10.1080/1093452090 2784583

Mganga N (2014) The potential of bioaccumulation and translocation of heavy metals in plant species growing around the tailing dam in Tanzania. Int J Sci Technol 3:690-697

Migaszewski ZM, Gałuszka A (2015) The characteristics, occurrence, and geochemical behavior of rare earth elements in the environment: A review. Crit Rev Environ Sci Technol 45:429-471. https://doi.org/10.1080/10643 389.2013.866622

Murtaza G, Javed W, Hussain A, Qadir M, Aslam M (2017) Soil-applied zinc and copper suppress cadmium uptake and improve the performance of cereals and legumes. Int J Phytoremediation 19:199-206. https://doi.org/10. 1080/15226514.2016.1207605

Mwamba TM, Ali S, Ali B, Lwalaba JL, Liu H, Farooq MA, Shou J, Zhou W (2016) Interactive effects of cadmium and copper on metal accumulation, oxidative stress, and mineral composition in Brassica napus. Int J Environ Sci Technol 13:2163-2174. https://doi.org/10.1007/ s13762-016-1040-1

Nagajyoti PC, Lee KD, Sreekanth TVM (2010) Heavy metals, occurrence and toxicity for plants: A review. Environ Chem Lett 8:199-216. https://doi.org/10.1007/ s10311-010-0297-8

Ordóñez-Barona C, Sabetski V, Millward AA, Steenberg J (2018) De-icing salt contamination reduces urban tree performance in structural soil cells. Environ Pollut 234:562-571. https://doi.org/10.1016/j.envpol.2017.11. 101

Pachura P, Ociepa-Kubicka A, Skowron-Grabowska B (2016) Assessment of the availability of heavy metals to plants based on the translocation index and the bioaccumulation factor. Desalin Water Treat 57:1469-1477. https:// doi.org/10.1080/19443994.2015.1017330

Palit S, Sharma A, Talukder G (1994) Effects of cobalt on plants. Bot Rev 60:149-181. https://doi.org/10.1007/ BF02856575

Peng Y, Chen J, Wei H, Li S, Jin T, Yang R (2018) Distribution and transfer of potentially toxic metal (loid)s in Juncus effusus from the indigenous zinc smelting area, northwest region of Guizhou. Ecotoxicol Environ Saf 152:24-32. https://doi.org/10.1016/j.ecoenv.2018.01. 026

Rahman KZ, Wiessner A, Kuschk P, Van Afferden M, Mattusch J, Müller RA (2014) Removal and fate of arsenic in the rhizosphere of Juncus effusus treating artificial wastewater in laboratory-scale constructed wetlands. Ecol Eng 69:93-105. https://doi.org/10.1016/j.ecoleng.2014.03.050 
Retamal-Salgado J, Hirzel J, Walter I, Matus I (2017) Bioabsorption and bioaccumulation of cadmium in the straw and grain of maize (Zea mays L.) in growing soils contaminated with cadmium in different environment. Int $\mathbf{J}$ Environ Res Public Health 14:1399. https://doi.org/10. 3390/ijerph14111399

Schlesinger WH, Bernhardt ES (2020) The Lithosphere. In: Biogeochemistry: An Analysis of Global Change, 4th edn. Elsevier, Amsterdam. https://doi.org/10.1016/b978-0-12814608-8.00004-9

Schmoger MEV, Oven M, Grill E (2000) Detoxification of arsenic by phytochelatins in plants. Plant Physiol 122:793-801. https://doi.org/10.1104/pp.122.3.793

Singh B, Cattle SR, Field DJ (2014) Edaphic Soil Science, Introduction to. Encycl Agric Food Syst 3:35-58. https:// doi.org/10.1016/B978-0-444-52512-3.00092-9

Syranidou E, Christofilopolus S, Kalogerakis N (2017) Juncus spp.-The helophyte for all (phyto)remediation purposes? N Biotechnol 38:43-55. https://doi.org/10.1016/j.nbt. 2016.12.005

Tsonev T, Lidon FJC (2012) Zinc in plants-An overview. Emirates J Food Agri 24:322-333

Tyler G, Olsson T (2001) Plant uptake of major and minor mineral elements as influenced by soil acidity and liming. Plant Soil 230:307-321. https://doi.org/10.1023/A:10103 14400976

Usman ARA, Kuzyakov Y, Stahr K (2005) Effect of immobilizing substances and salinity on heavy metals availability to wheat grown on sewage sludge-contaminated soil. Soil Sediment Contam 14:329-344. https://doi.org/10.1080/ 15320380590954051

Wang L, Liang T, Hu A, Ding S, Zhang C-S, Yan X (2005) Accumulation and fractionation of rare earth elements in soil-rice systems. J Rare Earths 23:747-752

Wang L, Xu J, Jia W, Chen Z, Xu Z (2020) Chloride salinity in a chloride-sensitive plant: Focusing on photosynthesis, hormone synthesis and transduction in tobacco. Plant Physiol Biochem 153:119-130. https://doi.org/10.1016/j. plaphy.2020.05.021
Wang P, Menzies NW, Dennis PG, Guo J, Forstner C, Sekine R, Lombi E, Kappen P, Bertsch PM, Kopittke PM (2016) Silver nanoparticles entering soils via the wastewatersludge-soil pathway pose low risk to plants but elevated $\mathrm{Cl}$ concentrations increase Ag bioavailability. Environ Sci Technol 50:8274-8281. https://doi.org/10.1021/acs.est. $6 \mathrm{~b} 01180$

Weggler K, McLaughlin MJ, Graham RD (2004) Effect of chloride in soil solution on the plant availability of biosolid-borne cadmium. J Environ Qual 33:496-504. https:// doi.org/10.2134/jeq2004.4960

White PJ, Broadley MR (2001) Chloride in soils and its uptake and movement within the plant: A review. Ann Bot 44:967-988. https://doi.org/10.1006/anbo.2001.1540

Wiessner A, Kappelmeyer U, Kaestner M, Kuschk P (2013) Response of ammonium removal to growth and transpiration of Juncus effusus during the treatment of artificial sewage in laboratory-scale wetlands. Water Res 47:42654273. https://doi.org/10.1016/j.watres.2013.04.045

Xiong ZT, Feng T (2001) Enhanced accumulation of lead in by soil-applied chloride salts. Bull Environ Contam Toxicol 67:67-74. https://doi.org/10.1007/s00128-001-0092-0

Yadav A, Goyal D, Prasad M, Singh TB, Shrivastav P, Ali A, Dantu PK (2020) Bioremediation of toxic pollutants: Features, strategies, and applications. In: Naeem M, Ansari A, Gill S (eds) Contaminants in Agriculture. Springer, Cham. https://doi.org/10.1007/978-3-030-41552-5_18

Zare K, Sheykhi V, Zare M (2020) Investigating the heavy metals' removal capacity of some native plant species from the wetland groundwater of Maharlu Lake in Fars province. Int J Phytoremediation 22:781-788. https://doi.org/ 10.1080/15226514.2019.1710815

Publisher's Note Springer Nature remains neutral with regard to jurisdictional claims in published maps and institutional affiliations. 